\title{
Review on Thermal Management Systems Using Phase Change Materials for Electronic Components, Li-ion Batteries and Photovoltaic modules
}

\author{
Ziye Ling ${ }^{1}$, ZhengguoZhang ${ }^{1}$, Guoquan $\mathrm{Shi}^{1}{ }^{1}$, Xiaoming Fang ${ }^{1}$, Lei Wang ${ }^{1}$, \\ Xuenong Gao ${ }^{1}$, Yutang Fang ${ }^{1}$, Tao $\mathrm{Xu}^{1}$, Shuangfeng Wang ${ }^{1}$, Xiaohong $\mathrm{Liu}^{2}$ \\ ${ }^{1}$ Key Laboratory of Enhanced Heat Transfer and Energy Conservation, the Ministry \\ of Education, School of Chemistry and Chemical Engineering, South China \\ University of Technology, Guangzhou 510640, China. \\ 2 Automotive Department, Guangdong Industry Technical College, Guangzhou \\ 510300, China. \\ * The corresponding author, Tel.: +86 208711 2845, Fax: +86 208711 3870, Email: \\ cezhang@scut.edu.cn
}




\begin{abstract}
:
Improper operating temperature will degrade the performances of electronic components, Li-ion batteries and photovoltaic (PV) cells, which calls for a good thermal management system. In this paper, specific attention is paid to the thermal management systems based on phase change materials (PCMs). Performances of the PCM-based thermal management systems for for each kind of these three devices along with the type of PCM used, thermal properties of that kind of PCM, like phase change temperature, enthalpy of phase change and thermal conductivity are discussed. Discussion in detail on techniques to improve the thermal conductivity of PCMs are made because of its crucial influence. Advanced-structure heatsinks with multi-layer PCMs and hybrid passive heatsinks combined with active cooling are also introduced. The PCM-based thermal management system is powerful in ensuring electronic devices, Li-ion batteries and photovoltaic cells working safely and efficiently.
\end{abstract}

Keywords: Thermal management system; phase change material; electronic component; Li-ion battery; photovoltaic module 


\section{Introduction}

In recent years, miniaturization of electronic components as well as enhancement on their performance has led to the emergence of high power devices with high packing densities. The statistics show the performance and density of semiconductor transistors has doubled every 18 months since 1970 which agreed with the prediction of Moore's law [1, 2]. According to the Moore's Law, heat fluxes of the chips are approaching $300 \mathrm{~W} \mathrm{~cm}^{-2}$ in the near future [3]. Pursuits of high performance and high integration increase the heat flux of electronic components greatly, presenting a severe bottleneck in the development of the electronic industry[4, 5]. Heat density of electronic chips has increased remarkably in recent years.

Owing to the high cell voltage, high energy/power density and the long cycle life, Li-ion batteries are extensively used as power sources for a wide range of electronic devices such as cell phones, cameras, and laptops, and are considered to be the ideal power sources for next generation vehicles, electric vehicles (EVs) and hybrid electric vehicles (HEVs) [6-11]. However, accumulated heat in the batteries brings concerns of performance drops and safety hazards. An excess local temperature rise in Li-ion batteries may cause capacity fade, accelerate reduction of cycle life [12-14], and lead to thermal runaway of individual cells which is likely spread to the adjacent batteries, causing the failure of the whole battery pack $[15,16]$.

High operating temperature is also lethal to PV cells. The output power of crystalline silicon module is to decrease by $0.4-0.5 \%$ for each $1 \mathrm{~K}$ rise in the cell temperature above the characteristic power conversion temperature $25{ }^{\circ} \mathrm{C}[17,18]$. 
As the temperature-sensitive devices including electronic equipment, Li-ion batteries and photovoltaic modules are getting highly integrated and more compact, good thermal management systems are becoming crucial for providing good performance and long service life. However, traditional thermal management technologies such as active air cooling and liquid cooling systems are constrained because of the low heat transfer rate, high initial and maintenance cost, or the complexity of equipment. Active cooling systems like forced air/liquid cooling need fans or pumps and heat sinks, which makes the system complex and cumbersome. Therefore, it is quite necessary to develop novel thermal management systems with rapid heat dissipation to keep the electronic components, Li-ion batteries and solar cells working under the optimum temperature range.

PCMs that absorbs or releases a large quantity of latent heat when it undergoes phase change from solid state to liquid state or vice versa has been commonly used in thermal energy storage systems [19-22]. The passive thermal management systems using PCMs stand out from the traditional thermal control systems with its lightness, compactness and high efficiency. Consequently, the thermal management systems using PCMs have attracted an increasing interest in recent years. In the present review, we will give a brief introduction into the requirements for the PCMs used in the thermal management systems. Recent advancements in the thermal management systems containing PCMs for electronic components, Li-ion batteries and PV cells will then be emphasized. For each part, the basic structure of the thermal management system, the type of PCMs used most frequently, techniques to improve the thermal 
performances and work yet to be done will be covered.

\section{Requirements of PCMs used in thermal management systems}

The PCMs used in thermal management systems should meet the following requirements [23]: 1) phase change temperature (PCT) falling within the desired range; 2) large latent heat, specific heat and thermal conductivity; 3) low volume expansion and low/no supercooling during freezing; 4) non-poisonous, non-corrosiveness, nonflammable, non-explosive and chemically stable; 5) low cost.

Because numerous chemical substances can be used as PCMs, choosing one with suitable melting points, large latent heat, chemical stability and low cost is not too hard. However, most PCMs suffer a serious disadvantage of low thermal conductivity, which is an impediment to the application of PCMs in thermal management systems. Measures to improve the thermal conductivity of PCMs have been taken in following ways: 1) adding thermal conductive additives, like carbon-fibre chips, aluminum powder or nano-materials into PCMs [24-29]; 2) absorbing PCMs into porous metal foam or expanded graphite (EG) matrices to form composites [30-32]; 3) adding metal screens/spheres or utilizing metal fins [33-35].

Table 1 summarizes the thermal conductivity enhancing approaches for PCMs. Comparing all kinds of methods, absorbing PCMs into EG matrix is the ideal choice. The EG matrix improves the thermal conductivity of PCMs significantly as other additives do. Moreover, the capillary forces keep the PCM absorbed into EG with no leak even when PCM melts. It is reported that mass fraction of PCM in the 
form-stable PCM/EG composites can be as high as 90\% [36].

\section{PCM-based electronic equipment thermal management systems}

The reliability of electronic components is greatly affected by the operating temperature. As the U.S. Air Force indicated, over 55\% of failures in electronics are caused by elevated temperature [49]. Moreover, as indicated by Patapoutian [50], if the temperature of a handheld device is over $45{ }^{\circ} \mathrm{C}$, users would feel discomfort. Therefore, a good thermal management system for electronics is necessary. The passive thermal management system based on PCMs can store the heat dissipated from chips in the form of sensible heat and latent heat of PCM. The latent heat is especially effective to absorb heat and slow down the temperature rise of chips. Organic PCMs, with a proper PCT ranging from $35 \sim 60{ }^{\circ} \mathrm{C}$, low degree of supercooling and large heat of fusion (HOF) are commonly used in the the passive thermal management systems for electronic components.

Alawadhi and Amon [51] presented a thermal management system using the PCM eicosane with the PCT of $37{ }^{\circ} \mathrm{C}$ and specific latent heat of $241 \mathrm{~kJ} \mathrm{~kg}^{-1}$. As shown in Fig. 1, this system has a very simple structure by attaching the PCM thermal control unit (TCU) to a heater that simulated a heating chip. The added PCM TCU efficiently slowed down the temperature rise rate because of the large heat absorbing capacity during phase changed. A reduced temperature fluctuation of the heater were also found for the system with the PCM TCU.

Hodes et al. [52] examined the performance of a PCM-based thermal management 
system for an ABS handset mock-up. Results showed that with a power $3 \mathrm{~W}$ supplied to the handset, the $10.9 \mathrm{~g}$ Thermasorb-122 (PCT: $48^{\circ} \mathrm{C}, \mathrm{HOF}: 160 \mathrm{~kJ} \mathrm{~kg}^{-1}$ ) and $9.5 \mathrm{~g}$ tricosane (PCT: $50^{\circ} \mathrm{C}$, HOF: $234 \mathrm{~kJ} \mathrm{~kg}^{-1}$ ) ensured 17 minutes and 35 minutes longer before the handset is too hot to use, compared with the 6 minutes without thermal management.

Kandasamy et al. [53] applied paraffin wax to the thermal management system for a portable electronic device and investigated the performance of the system under different orientations of the package to gravity. The question on whether the orientation had influences on the heat transfer was raised because the natural convection inside liquid PCMs dominated the heat exchange between walls of heatsink and PCMs and natural convection was affected by the orientation. In Kandasamy's study, melting time and maximum heater temperature were compared among three orientations of the package (horizontal, vertical and slanted at $45^{\circ}$ ). Since there were no big differences in the melting time and maximum temperature of heater, the effect of the orientation on the thermal performance of the PCM package was thought to be negligible. The work by Wang et al. [54] also indicated the effect of orientation was limited.

The thermal management system based on organic PCMs have shown good performances in temperature control of electronic components. However, these materials have a fatal problem, its low thermal conductivity. The low thermal conductivity at the magnitude of $0.1 \mathrm{~W} \mathrm{~m}^{-1} \mathrm{~K}^{-1}$ brings a big thermal resistance between heat source and PCM, leading to an undesirable extra high temperature for 
chips. Krishnan et al. $[55,56]$ numerically compared the performance among metallic PCMs, pure organic PCMs and organic PCMs which was imbedded inside a thermal conductivity enhancer made of metal foam. Compared with the the metallic PCMs and the eicosane with thermal conductivity enhanced by an Al foam, the junction temperature with thermal controlled by pure eicosane is nearly $300 \sim 400{ }^{\circ} \mathrm{C}$ higher.

Improving thermal conductivity of PCMs by inserting thermal enhancer made of metals is useful. Nayak et al. [57] compared the performances of finned-heatsinks containing eicosane with three different structures via the numerical approach. The heatsink with rod fins was showed better performance to reduce the chip temperature and keep the temperature distribution uniform compared than the metal matrix and plate-finned heatsinks. Mahmoud et al. [58] experimentally investigated the effects of heat sink configurations on PCM based heat sinks performance for cooling electronic devices, which is shown in Fig. 2. With advantages of light weight, ease of assembly and reduced cost, the use of honeycomb insert were more recommended. For the heatsink with parallel/crossed fins, increasing the fins number was proved effective to enhance heat transfer to PCMs and lower the peak temperature, especially at a high power level. The conclusion is supported by Dubovsky et al. [59]. Baby et al. [60, 61] also found out a good performance the PCM-based thermal management system with pin fins. However, in a container with a fixed volume, increasing the pin fin number did not always improve the thermal performance. When the volume fraction of fins was $9 \%$, the enhancement brought by pin fins was the highest. Further increase of pin fin number degraded the thermal management performance due to the lack of PCM. 
Metal foams are also used to improve the thermal performance. Qu et al. [62] measured the performances of three types of heat sinks with: 1) a solid copper basement, 2) a hollow container filled with pure paraffin, 3) a copper foam saturated with paraffin, used in an electronic thermal management system. As shown in Fig. 3(a), compared with the basement made of copper, the peak temperature of the chip with temperature controlled by the hollow container of pure PCM dropped drastically and if the pure PCM was replaced by the copper metal foam-PCM composite, a further drop of peak temperature could be observed. It was also found that the surface temperature was more sensitive to porosity than pore density of copper foam, which means the volume fraction of copper plays a more important role in reducing the peak temperature of electronic chips than the pore size, as shown in Fig. 3(b).

Sanusi et al. [63] studied the nano-enhanced paraffin for electronics thermal management at heat loads from 100-1000 W with various masses and aspect ratios. Results showed that the graphite nano-fibers/paraffin composites offered longer temperature control period and lower peak temperature than pure paraffin.

Yin et al. [64] developed an electronic component thermal management system with PCM/EG composites. With thermal conductivity enhanced by EG, faster heat absorption and release was observed, as shown in Fig. 4(a). Compared with traditional forced air cooling system, a 1.25-1.30 times higher apparent heat transfer coefficient and a lower temperature for electronic components was achieved in the passive thermal management system of PCM/EG composites, which is shown in Fig. 4(b). 
in the electronics temperature control, especially for the PCMs with thermal conductivity enhanced. Nevertheless, the PCMs-based passive thermal management systems are only suitable for equipment working periodically. The latent heat of PCMs is run out and heat is generated continuously, the temperature keeps rising until a steady state reached. At this state, the heat generated by chips is conducted by PCMs to the outside boundary of heatsink and exchanged with air by natural convection. Due to the poor efficiency of natural convection, extra heat dissipation techniques must be taken to ensure the proper functioning of electronic equipment at the steady state.

Alawadhi [65] designed a thermal management system by combining a layer of PCM TCU with the forced air cooling. The forced convection of air provided extra driven force to lower the steady state temperature of chips. The peak temperature could be restricted within $50{ }^{\circ} \mathrm{C}$ at the Reynolds number of 500 and power of $10 \mathrm{~W}$ for each of three heating blocks. The n-eicosane used as the PCM also played an important role in the temperature control process. It was found that the PCM was effective in reducing the peak temperature by $13.7 \%-26.8 \%$, and postponing the time to reach the peak temperature.

Therefore, the PCM-based heat sink combining with forced air convection not only shows better than the system without fans, but also is superior to the traditional air-cooled heatsink with no PCMs. The mixed technique with active cooling ensures the reliability of PCM-based heatsink at a steady state.

Wang and Baldea [66] examined a hybrid cooling system for mobile devices 
combining PCMs with active cooling. With the use of PCMs, the energy consumption of active cooling was reduced, and so was the chip temperature fluctuation when sudden heat was induced.

In addition, other complex studies on complex heatsinks to improve performances of PCMs have conducted. Weng et al. [67] studied the cooling effectiveness of a mixed cooling system by combining a heat pipe with PCM thermal control unit for electronic cooling. It was found that a $46 \%$ of the fan power consumption was saved compared with only a heat pipe. Yin et al. [46] installed a PCM heat storage at the condensation part of the two heat pipes. Compared with the traditional heatsink without PCM, the heatsink with PCM was able to reduce the peak temperature of the chip and improve the apparent heat dissipation rate by 1.36 2.98 times.

Shaikh and Lafdi [68] presented a structure of heat sinks with three-layer PCMs, as shown in Fig. 5. For 3PCM composite, the melting temperature was the lowest for the PCM farthest away from the heat source while for the 1PCM composite, melting temperatures of all PCMs were the same. 3PCM composite had great energy storage and heat dissipation capacity, leading to a lower maximum junction temperature than 1PCM. This conclusion was supported by Yaquinto and Wirtz, with similar phenomenon observed for the stratified PCMs [69].

Applications of the thermal management system using PCMs have shown that it is efficient to use proper PCMs to control the temperature of electronic equipment, at both the transient and steady state. PCMs mostly used are organic materials which need extra treatments to improve its poor thermal conductivity. Few researches 
examined the application of inorganic materials because of the supercooling and corrosiveness. However, the inorganic materials mostly own the supreme thermal conductivity. Efforts to reduce the supercooling and corrosiveness of inorganic materials should also be made, as the efforts have been made on the thermal conductivity enhancement of organic materials.

\section{PCMs used in battery thermal management system (BTMS)}

According to the research from United States Advanced Battery Consortium (USABC) in the Freedom CAR, the calendar lifetime of batteries should be at least 15 years for HEVs and 10 years for EVs[70]. In terms of cycle life, a lifetime up to 3000 deep cycles are required for high energy applications [71]. Losses of capacity and power of batteries are irreversible. Although the mechanisms of capacity and power fades are not fully clear, many works have indicated the growth of solid electrolyte interface (SEI), loss of active lithium and lithium inventory and side reactions might contribute to the loss of capacity/power of Li-ion batteries. Losses of power and capacity are highly temperature dependent. Table 2 summaries the studies on relationships between Li-ion battery capacity/power fade and cycling temperature. It is easy to draw a conclusion from Table 2 that undesired operating temperature will accelerate the aging process of $\mathrm{Li}$-ion batteries. The operating temperature of battery pack which is too high or too low will suppress the performances of batteries [72-77]. In addition, as mentioned at Introduction, thermal runaways caused by the overheating of batteries are likely to trigger fire or explosion accidents and failure of the whole battery pack [78]. A good BTMS is indispensable for Li-ion batteries. 
Väyrynen recommended [86] that Li-ion batteries be operated within the temperature range between $-20{ }^{\circ} \mathrm{C}$ to $60{ }^{\circ} \mathrm{C}$, while Pesaran [87] pointed out that the best operating temperature should range between $25^{\circ} \mathrm{C}$ and $40{ }^{\circ} \mathrm{C}$, and the maximum temperature difference in the battery pack should not exceed $5^{\circ} \mathrm{C}$. The commonly used BTMSs are forced air convection cooling systems. However, the poor effectiveness of air cooling [88] show that the traditional BTMSs are not the best choice.

In order to overcome the disadvantages of the conventional BTMS, Al-Hallaj and Selman [89] firstly proposed a passive BTMS based on PCMs. The structure of PCM-based BTMS is quite simple by filling the gap between batteries with PCMs as shown in Fig. 6 [10]. Taking advantage of large latent heat of PCMs during phase change, temperature of batteries could be maintained within the range around the PCT of PCMs for a long time. With thermal conductivity improved, the PCMs could minimize the temperature difference in the battery pack to eliminate the potential propagable thermal runaways. Thanks to the robust heat dissipation capability and the compact structure with no blowers, pumps and flow distributors which require extra energy input, the PCM-based passive BTMS seems to be a perfect choice.

Ramandi et al. [90] presented an improved configuration for the PCM-based passive BTMS. The configuration consisted of double layer PCMs, as shown in Fig. 7. 


\subsection{Capability in the control of temperature rise}

Al-Hallaj and Selman [91] found under the conditions of near insulating with the effective heat transfer coefficient of natural convection of $1 \mathrm{~W} \mathrm{~m} \mathrm{~m}^{-1}$, the temperature of a 100 Ah battery module with PCM was able to be maintained at about $8{ }^{\circ} \mathrm{C}$ lower than without PCM at the end of discharge. Al-Hallaj et al. [92] recorded the temperature curves of a Li-ion battery pack used in electric scooter under different thermal management systems. The result showed the PCM brought a $8^{\circ} \mathrm{C}$, which was $50 \%$ drop for the temperature rise of battery cells discharging at a $\mathrm{C} / 1$ rate. The aluminum foam was used to improve the thermal properties of PCM and a further temperature drop of $1 \sim 2{ }^{\circ} \mathrm{C}$ for cells was found. However, in both works, the PCT of PCM used were not mentioned.

Mills et al. [30]measured the heat generation rate of $186502.2 \mathrm{Ah}$ batteries and numerically examined the performance of a PCM-based BTMS. The PCM used was RT 42 with PCT of $42{ }^{\circ} \mathrm{C}$ and the HOF of RT42/EG composite was $127 \mathrm{~kJ} \mathrm{~kg}^{-1}$. It was found this BTMS could meet the criteria of an operating temperature lower than $55{ }^{\circ} \mathrm{C}$ even at a high discharge rate and elevated temperature. The PCM/EG composite was also proved to be compact with a low volume expansion.

Duan and Naterer [93] used an electric heater to simulate a battery. PCMs used in this work were two commercial PCMs RPCM(PCT:18 $\left.{ }^{\circ} \mathrm{C}, \mathrm{HOF}: 195 \mathrm{~kJ} \mathrm{~kg}^{-1}\right)$ and T-PCM(PCT: $50^{\circ} \mathrm{C}, \mathrm{HOF}$ : not mentioned). With a given power of $1.36 \mathrm{~W}$ and the ambient temperature of $25{ }^{\circ} \mathrm{C}$, the temperature of heater submerged into the RPCM stabilized at $40{ }^{\circ} \mathrm{C}$, which was nearly $30{ }^{\circ} \mathrm{C}$ lower than the case without RPCM. The 
temperature of heater wrapped by a T-PCM jacket could be kept $6{ }^{\circ} \mathrm{C}$ lower than without PCM.

PCM-based BTMS has a good effectiveness on cooling Li-ion battery at stressful conditions (i.e. at high discharge rates and at high operating or ambient temperature). Sabbah et al. [94] used the PCM-graphite composites with melting range between $52 \sim 58{ }^{\circ} \mathrm{C}$ to regulate battery temperature. It was reported that at gentle conditions at a low discharge rate of $2 \mathrm{C}$ or low ambient temperature of $25^{\circ} \mathrm{C}$, there was not big difference in the thermal management performance between active air cooling and passive PCM-based BTMS, as shown in Fig. 8(a). But with the increased discharge rate up to $6.67 \mathrm{C}$ and ambient temperature up to $45^{\circ} \mathrm{C}$, the PCM-based passive BTMS showed much better performance as in Fig. 8(b). The maximum temperature of battery with air-cooling $(\mathrm{Re}=1347)$ exceeded $60{ }^{\circ} \mathrm{C}$ even with a massive fan power input of $73 \mathrm{~W}$, while the BTMS based on PCMs showed a definite advantage as the maximum temperature was controlled within $55^{\circ} \mathrm{C}$ passively.

Somasundaram et al.[95] presented a two-dimensional thermal-electrochemical coupled model for a commercially available spiral-wound Li-ion battery with a passive thermal management system. Both electrochemical and thermal behaviors could be tracked in this model. The reversible heat was considered to be the major heat source at a low discharge rate around $1 \mathrm{C}$ while ohmic heat contributed the most at a higher discharge rate up to $5 \mathrm{C}$. The maximum temperature of the battery cell with PCM was $16{ }^{\circ} \mathrm{C}$ lower than without PCM at 640s under a 5C discharge, which verified the effectiveness of PCM-based BTMS. This multi-physics model showed 
powerful in multi-objective optimization of Li-ion battery cell with passive thermal management.

A higher exergy efficiency of heat transfer for the configuration with double layer of PCMs than single layer was reported by Ramandi et al. [90]. Thermal properties of PCMs used in that work are listed in Table 3. The combination of PCMs for the double-layer PCMs included: PCM-1+PCM-2, PCM-1+PCM-3 and PCM-1+PCM-4. In all cases, PCM-1, capric acid was at the first layer. The battery temperature with the thermal management of the double-layer PCMs was much lower than with single-layer PCMs, as shown in Fig. 9. The combination of PCM-1 and PCM-4 showed the highest exergy efficiency but the battery temperature in the combination of PCM-1 and PCM-3 was the lowest, as shown in Fig. 9(b), which meant that the improvement of exergy did not necessarily improve the temperature control performance.

\subsection{Efficiency in the control of batteries temperature uniformity}

Besides the low temperature rise, a uniform temperature distribution in the whole system is another key to ensure batteries work efficiently. The different operating temperatures let battery cells undergo capacity fades at different rates, resulting in lower capacity utilization and faster capacity fading.

As indicated by Rao et al. [96], a proper thermal conductivity ratio of PCM over battery cell as big as 4 was the key to maintain the temperature differences among batteries within desirable range.

Kizilel et al. [10] applied the PCM/EG composites with melting range from 42 45 
${ }^{\circ} \mathrm{C}$, HOF of $127 \mathrm{~kJ} \mathrm{~kg}^{-1}$ and thermal conductivity of $16.6 \mathrm{~W} \mathrm{~m}^{-1} \mathrm{~K}^{-1}$ to the BTMS. Compared with the air cooling systems, the PCM-based BTMS reduced the temperature difference from $3{ }^{\circ} \mathrm{C}$ to $0.2{ }^{\circ} \mathrm{C}$, as illustrated in Fig. 10 . The high capacity of heat absorption and diffusion of PCMs with thermal conductivity enhanced showed effective to prevent the thermal runaway propagation caused by the overheating of a single cell. Kizilel et al.[97] found that with the same PCM/EG composites, temperature differences between the battery in the center and the battery at the corner in the pack reached $3{ }^{\circ} \mathrm{C}$ and $10^{\circ} \mathrm{C}$ for the BTMS with/without PCM at the $\mathrm{C} / 1$ discharge rate, which was a significant drop.

Sabbah et al. [94] also showed that the cell mean temperature difference (CMTD) in the PCM/EG composite based BTMS did not exceed $0.5^{\circ} \mathrm{C}$ in stressful conditions with a discharge rate of $6.67 \mathrm{C}$ and the ambient temperature of $45^{\circ} \mathrm{C}$. However, with active cooling, the CMTD reached $2{ }^{\circ} \mathrm{C}$ with a discharge rate of $2 \mathrm{C}$ and up to $4.8^{\circ} \mathrm{C}$ with discharge rate of 6.67 C. Unfortunately, the CMTD increased sharply with the increase of air flow rate. A lower maximum temperature in the battery pack would be achieved with sacrifices of temperature uniformity and high power input.

\subsection{Improvement in cycle performance of PCM-based BTMS}

BTMS is designed to make sure better cycle performances of batteries, therefore, how much the performance could be improved or how much capacity fade could be avoided is of great interest.

Mills et al. [37] monitored the capacity fade of Li-ion battery with battery cycling at $\mathrm{C} / 1$ discharge rate and $\mathrm{C} / 3$ charge rate within 300 cycles. It was found that the 
discharge capacity decreased by $0.09 \mathrm{~W}$ h/cycle with PCM and decreased by $0.20 \mathrm{~W}$ h/cycle without PCM.

Al-Hallaj et al. [98] investigated the performance of a 4.8 Ah battery module that discharged at currents of $4.8 \mathrm{~A}, 8 \mathrm{~A}$ and $10 \mathrm{~A}$ until the voltage dropped down to the lower cut-off voltage. Without PCM, the battery ran for $56 \mathrm{~min}, 20 \mathrm{~min}$ and $12.7 \mathrm{~min}$ which meant $93 \%, 55 \%$ and $44 \%$ of its nominal capacity was used. While with PCM-based BTMS, the Li-ion battery was able to utilize $90 \%$ of the nominal capacity at a discharge current of $10 \mathrm{~A}$ and ambient temperature of $45^{\circ} \mathrm{C}$.

Further work by Kizilel et al. [97] also confirmed the effectiveness of PCM-based BTMS on Li-ion battery cycle life. They found that the discharge capacity decreased at a rate of $12 \mathrm{mAh} / \mathrm{cycle}$ when no PCM was used whereas the capacity fade rate was only about 6 mAh/cycle with PCM, as depicted in Fig. 11.

The passive BTMS using PCMs have shown highlights in the regulation of power battery temperature and the temperature uniformity, which improves the performances and prolongs the lifespan for Li-ion batteries. Because of the high thermal conductivity, high compactness, shape flexible and low thermal expansion, the PCM/EG composites with melting range from $40 \sim 60{ }^{\circ} \mathrm{C}$ are favorite PCMs used in BTMSs.

The fatal problem that restrict the application of passive BTMS using PCMs to EVs/HEVs is the heaviness. Khateeb et al. [99] described a detailed procedure of designing a passive BTMS for Li-ion batteries. Large amount of PCM is necessary to make sure the total latent heat of PCM must match the heat dissipated by batteries. 
For example, the total weight of the Li-ion battery module for an electric scooter was $1.2 \mathrm{~kg}$, but the weight of battery cells was $756 \mathrm{~g}$, accounting for $63 \%$ and the PCM module accounted for the rest of $37 \%$. Power batteries used for EVs/HEVs need to work at higher discharge rate and longer period, which will definitely increase the mass proportion of PCM module. The large mass of PCM module is a big burden for vehicles and measures must be taken.

\section{PCMs used in photovoltaic modules thermal management}

It is known that part of the solar energy absorbed by a photovoltaic cell is converted into electrical energy while the rest is converted into heat, resulting in the increase in the temperature of the solar cell. The operating temperature of a photovoltaic device could reach as high as $80^{\circ} \mathrm{C}$ at a high solar radiation intensity [100]. The elevated temperature induces an increase in open-circuit current but a decrease in open circuit voltage. The overall effect of changes in current and voltage causes a drop for the output power of PV cells [101]. As indicated by Jiang et al. [102], the maximum output power of PV modules under $1000 \mathrm{~W} \mathrm{~m}^{-2}$ could decrease from $240 \mathrm{~W}$ to $196 \mathrm{~W}$ as the temperature increased from $0{ }^{\circ} \mathrm{C}$ to $75{ }^{\circ} \mathrm{C}$. It is commonly believed that, when the temperature is above $25{ }^{\circ} \mathrm{C}$, the power output of crystalline silicon modules are likely to decrease by approximately $0.4 \% \sim 0.65 \% \mathrm{~K}^{-1}$ $[103,104]$. The goal of thermal management systems for PVs is to control the temperature as low to $25^{\circ} \mathrm{C}$ as possible.

Researchers believe that PCM-based thermal management systems are effective to 
regulate the temperature of photovoltaic modules and reduce the loss of photoelectric conversion efficiency. Huang et al. [105] found that the temperature of front surface of the PV/PCM system could be maintained below $36.4{ }^{\circ} \mathrm{C}\left(33{ }^{\circ} \mathrm{C}\right)$ for 80 min $(150$ $\min )$ at $1000 \mathrm{~W} \mathrm{~m}^{-2}\left(750 \mathrm{~W} \mathrm{~m}^{-2}\right)$ insolation using the $\mathrm{PCM}$ with a phase transition temperature of $32{ }^{\circ} \mathrm{C}\left(26{ }^{\circ} \mathrm{C}\right)$. As predicted by a simulation using realistic one-day weather conditions, the maximum temperature of the front surface of the system with PCMs was under $34{ }^{\circ} \mathrm{C}$ and high electrical conversion efficiency was achieved, as illustrated in Fig. 12. Similar results were obtained by Biwole et al. [106], supporting the fact that PCM with PCT of $26{ }^{\circ} \mathrm{C}$ lowered the solar panel temperature and improved the efficiency.

The reduced Hasan et al.[107] used PCM-based thermal management to reduce the potential loss of temperature dependent photovoltaic efficiency and obtained a maximum temperature reduction of $18{ }^{\circ} \mathrm{C}$ for $30 \mathrm{~min}$ and $10{ }^{\circ} \mathrm{C}$ for $5 \mathrm{~h}$ at $1000 \mathrm{~W} \mathrm{~m}$ insolation.

Maiti et al. [108] used the paraffin wax of $56-58{ }^{\circ} \mathrm{C}$ melting range to limit the temperature of PV module in V-trough to $65{ }^{\circ} \mathrm{C}$. The low thermal conductivity of paraffin wax was improved by adding aluminum turnings. In the indoor experiment, the PV module temperature could be maintained at $65-68{ }^{\circ} \mathrm{C}$ for $3 \mathrm{~h}$ at an approximate $2300 \mathrm{~W} \mathrm{~m}^{-2}$ insolation with the PCM. However, the absence of PCM led to a rapid temperature rise to $90{ }^{\circ} \mathrm{C}$ within $15 \mathrm{~min}$. In the outdoor test, a reduction from $78{ }^{\circ} \mathrm{C}$ to $62{ }^{\circ} \mathrm{C}$ for the module temperature and $55 \%$ increase in output power was obtained. The PCM showed a good cycle reliability since the latent heat could be restored 
during solidification at night.

Tanuwijava et al. [109] showed the microencapsulated PCM could lower the temperature of PV cell and increase its efficiency. However, Tanuwijava also indicated an inappropriate aspect ratio of containers of microencapsulated PCM might cause extra temperature rise and output power drop compared with systems without PCMs. The performance differences between PCMs with PCT of $26{ }^{\circ} \mathrm{C}$ and PCT of $34{ }^{\circ} \mathrm{C}$ were narrow. However, the validity of this numerical model has yet to be checked.

The effectiveness of PCMs is also limited by their low thermal conductivities. Following works by Huang et al. $[110,111]$ investigated the thermal performances of PCMs with internal fins. Internal fins improved the effective thermal conductivity of PCMs and reduced the temperature rise of PV cells compared with systems without fins. As the fin spacing reduced, the maximum temperature decreased and a more uniform temperature distribution of PV cells was obtained.

Heat sinks with novel structures have been presented recently. Huang et al. [112] applied a heat sink with double-layer PCMs to the PV thermal management system , as shown in Fig. 13. The use of combinations of PCMs, each with a set of different phase transient temperatures, was expected to enhance the thermal regulation effect of the PV/PCM system and lengthen the thermal regulation time. Especially, the system with triangular metal cells for holding the PCMs could ease the volume expansion and extend the thermal regulation period, showing the best performance in the temperature control and improving the photoelectric transformation efficiency, which can be found 
in Fig.14.

Malvi et al. [113] presented a model to simulate a complex PV/solar-thermal (ST) system which incorporated PCM. The schematic is shown in Fig. 15. PV cells were mounted on top of copper plate with tubes embedded in. Beneath the copper plate was a layer of PCM. Both the PCM and water in the tubes were capable of absorbing the waste heat from PV cells. With the effective thermal management, the PV output increased by $9 \%$ in this hybrid PV/ST/PCM system compared with PV-only system.

The melting temperature of PCMs used in thermal management of PV modules are mainly around $25{ }^{\circ} \mathrm{C}$. The low thermal conductivity also restricted the performance of PCMs. But few researchers have made efforts to improve the thermal performance by increasing the thermal conductivity of PCMs. As mentioned above, PCM/EG composites bring a sharp increase in the thermal conductivity of PCMs and it is promising to apply the PCM/EG composites to the thermal management system of PV modules.

\section{Conclusions and Outlook}

By reviewing works on PCM-based thermal management system, PCMs have been proved to be excellent in moderating temperatures of electronic components, power batteries and photovoltaic modules. Compared to traditional active cooling by forced air/liquid convection which is complex and cumbersome, the passive thermal management system based on PCMs shows highlights of compactness, high efficiency, the very simplicity and no extra power input.

The requirement of temperature control differs among thermal management 
systems for electronic components, power batteries and photovoltaic cells. However, the PCMs with right phase transition temperatures are capable of keeping the temperature of those devices within the desired range for a long period.

The low thermal conductivity of traditional organic PCMs hinders rapid heat dissipation from cells to PCMs and the accumulation of heat leads to an extra high temperature. With thermal conductivity enhanced by inserting metal fins into PCMs or absorbing PCMs into EG matrices/metal foams, a quicker thermal response and better performances of thermal management systems can be achieved.

As a higher efficiency has been observed in passive thermal management systems with multi-layer PCMs with different PCT than single-layer PCMs, the multi-layer structure is likely to be applied to design and optimize the performances of the PCM-based thermal management system.

Even though PCMs have large amount of latent heat, the application of the passive thermal management system is only limited to the devices operating periodically. PCMs can delay the emergence of peak temperature of those devices, but fail to work after the latent heat of PCMs is run out. There must be a rest period for recovery of the latent heat between two cycles. Nevertheless, if incorporated with forced air convection or other ways of active cooling, the thermal management system will integrate the advantages of both passive and active thermal management systems. The hybrid system is surely able to reduce the peak temperature of the devices compared with passive-only systems and save the energy compared with active-only systems, which makes this hybrid system is promising. 


\section{Acknowledgements}

This work was supported by the Industry-University-Research Cooperation Project of

Guangdong Province and Chinese Education Ministry (2012B091000142, 2012B091100142), the Natural Science Foundation of Guangdong Province (S2011010001403), and the Joint Project of JST-MOST (2013DFG60080) 


\section{References}

[1] Moore GE. Progress in digital integrated electronics. IEEE; 1975. p. 11-3.

[2] Moore GE. Cramming more components onto integrated circuits. Proceedings of the IEEE. 1998;86:82-5.

[3] Robinson AJ. A Thermal-Hydraulic Comparison of Liquid Microchannel and Impinging Liquid Jet Array Heat Sinks for High-Power Electronics Cooling. Ieee T Compon Pack T. 2009;32:347-57.

[4] Mahajan R. Emerging directions for packaging technologies. 2002.

[5] Meindl JD. Low power microelectronics: Retrospect and prospect. Proceedings of the IEEE. 1995;83:619-35.

[6] Wakihara M. Recent developments in lithium ion batteries. Mat Sci Eng R. 2001;33:109-34.

[7] Zhou J, Notten PHL. Studies on the degradation of Li-ion batteries by the use of microreference electrodes. Journal of Power Sources. 2008;177:553-60.

[8] Kohler U, Kumpers J, Ullrich M. High performance nickel-metal hydride and lithium-ion batteries. Journal of Power Sources. 2002;105:139-44.

[9] Belharouak I, Sun YK, Liu J, Amine K. Li(Ni1/3Co1/3Mn1/3)O-2 as a suitable cathode for high power applications. Journal of Power Sources. 2003;123:247-52.

[10] Kizilel R, Sabbah R, Selman JR, Al-Hallaj S. An alternative cooling system to enhance the safety of Li-ion battery packs. Journal of Power Sources. 2009;194:1105-12.

[11] Karden E, Ploumen S, Fricke B, Miller T, Snyder K. Energy storage devices for future hybrid electric vehicles. Journal of Power Sources. 2007;168:2-11.

[12] Amine K, Chen CH, Liu J, Hammond M, Jansen A, Dees D, et al. Factors responsible for impedance rise in high power lithium ion batteries. Journal of Power Sources. 2001;97-8:684-7.

[13] Bloom I, Cole BW, Sohn JJ, Jones SA, Polzin EG, Battaglia VS, et al. An accelerated calendar and cycle life study of Li-ion cells. Journal of Power Sources. 2001;101:238-47.

[14] Aurbach D, Markovsky B, Rodkin A, Cojocaru M, Levi E, Kim HJ. An analysis of rechargeable lithium-ion batteries after prolonged cycling. Electrochim Acta. 2002;47:1899-911.

[15] Tobishima S, Yamaki J. A consideration of lithium cell safety. Journal of Power Sources. 1999;82:882-6.

[16] Spotnitz RM, Weaver J, Yeduvaka G, Doughty DH, Roth EP. Simulation of abuse tolerance of lithium-ion battery packs. Journal of Power Sources. 2007;163:1080-6.

[17] Krauter S, Hanitsch R, Wenham S. Simulation of thermal and optical performance of PV modules. Renewable Energy. 1994;5:1701-3.

[18] Norton B, Eames PC, Mallick TK, Huang MJ, McCormack SJ, Mondol JD, et al. Enhancing the performance of building integrated photovoltaics. Sol Energy. 2011;85:1629-64.

[19] Zalba B, Marín JM, Cabeza LF, Mehling H. Review on thermal energy storage 
with phase change: materials, heat transfer analysis and applications. Appl Therm Eng. 2003;23:251-83.

[20] Alkan C, Sarı A, Karaipekli A. Preparation, thermal properties and thermal reliability of microencapsulated n-eicosane as novel phase change material for thermal energy storage. Energ Convers Manage. 2011;52:687-92.

[21] Karaman S, Karaipekli A, Sarı A, Biçer A. Polyethylene glycol (PEG)/diatomite composite as a novel form-stable phase change material for thermal energy storage. Sol Energ Mat Sol C. 2011;95:1647-53.

[22] Tyagi VV, Buddhi D, Kothari R, Tyagi SK. Phase change material (PCM) based thermal management system for cool energy storage application in building: An experimental study. Energ Buildings. 2012;51:248-54.

[23] Rao Z, Wang S. A review of power battery thermal energy management. Renewable and Sustainable Energy Reviews. 2011;15:4554-71.

[24] Hamada Y, Ohtsu W, Fukai J. Thermal response in thermal energy storage material around heat transfer tubes: effect of additives on heat transfer rates. Sol Energy. 2003;75:317-28.

[25] Frusteri F, Leonardi V, Vasta S, Restuccia G. Thermal conductivity measurement of a PCM based storage system containing carbon fibers. Appl Therm Eng. 2005;25:1623-33.

[26] Zhang YP, Ding HH, Wang X, Yang R, Lin KP. Influence of additives on thermal conductivity of shape-stabilized phase change material. Sol Energ Mat Sol C. 2006;90:1692-702.

[27] Mettawee E-BS, Assassa GMR. Thermal conductivity enhancement in a latent heat storage system. Sol Energy. 2007;81:839-45.

[28] Zeng JL, Sun LX, Xu F, Tan ZC, Zhang ZH, Zhang J, et al. Study of a PCM based energy storage system containing Ag nanoparticles. J Therm Anal Calorim. 2007;87:369-73.

[29] Cui Y, Liu C, Hu S, Yu X. The experimental exploration of carbon nanofiber and carbon nanotube additives on thermal behavior of phase change materials. Sol Energ Mat Sol C. 2011;95:1208-12.

[30] Mills A, Al-Hallaj S. Simulation of passive thermal management system for lithium-ion battery packs. Journal of Power Sources. 2005;141:307-15.

[31] Zhang ZG, Fang XM. Study on paraffin/expanded graphite composite phase change thermal energy storage material. Energ Convers Manage. 2006;47:303-10.

[32] Lafdi K, Mesalhy O, Shaikh S. Experimental study on the influence of foam porosity and pore size on the melting of phase change materials. Journal of Applied Physics. 2007;102:083549--6.

[33] Saha SK, Srinivasan K, Dutta P. Studies on optimum distribution of fins in heat sinks filled with phase change materials. J Heat Trans-T Asme. 2008;130.

[34] Ettouney HM, Alatiqi I, Al-Sahali M, Al-Ali SA. Heat transfer enhancement by metal screens and metal spheres in phase change energy storage systems. Renewable Energy. 2004;29:841-60.

[35] Mazman M, Cabeza LF, Mehling H, Paksoy HO, Evliya H. Heat transfer enhancement of fatty acids when used as PCMs in thermal energy storage. Int J Energ 
Res. 2008;32:135-43.

[36] Wang WL, Yang XX, Fang YT, Ding J, Yan JY. Preparation and thermal properties of polyethylene glycol/expanded graphite blends for energy storage. Appl Energ. 2009;86:1479-83.

[37] Mills A, Farid M, Selman JR, Al-Hallaj S. Thermal conductivity enhancement of phase change materials using a graphite matrix. Appl Therm Eng. 2006;26:1652-61.

[38] Alva LH, Gonzalez JE, Dukhan N. Initial analysis of PCM integrated solar collectors. J Sol Energ-T Asme. 2006;128:173-7.

[39] Cheng WL, Zhang RM, Xie K, Liu N, Wang J. Heat conduction enhanced shape-stabilized paraffin/HDPE composite PCMs by graphite addition: Preparation and thermal properties. Sol Energ Mat Sol C. 2010;94:1636-42.

[40] Darkwa J, Zhou T. Enhanced laminated composite phase change material for energy storage. Energ Convers Manage. 2011;52:810-5.

[41] Hasse C, Grenet M, Bontemps A, Dendievel R, Sallee H. Realization, test and modelling of honeycomb wallboards containing a Phase Change Material. Energ Buildings. 2011;43:232-8.

[42] Karaipekli A, Sari A, Kaygusuz K. Thermal conductivity improvement of stearic acid using expanded graphite and carbon fiber for energy storage applications. Renewable Energy. 2007;32:2201-10.

[43] Li H, Liu X, Fang GY. Synthesis and characteristics of form-stable n-octadecane/expanded graphite composite phase change materials. Appl Phys a-Mater. 2010;100:1143-8.

[44] Sari A, Karaipekli A. Thermal conductivity and latent heat thermal energy storage characteristics of paraffin/expanded graphite composite as phase change material. Appl Therm Eng. 2007;27:1271-7.

[45] Siahpush A, O'Brien J, Crepeau J. Phase change heat transfer enhancement using copper porous foam. J Heat Trans-T Asme. 2008;130:-.

[46] Yin HB, Gao XN, Ding J, Zhang ZG. Experimental research on heat transfer mechanism of heat sink with composite phase change materials. Energ Convers Manage. 2008;49:1740-6.

[47] Zeng JL, Cao Z, Yang DW, Sun LX, Zhang L. Thermal conductivity enhancement of Ag nanowires on an organic phase change material. J Therm Anal Calorim. 2010;101:385-9.

[48] Zhang HZ, Wang XD, Wu DZ. Silica encapsulation of n-octadecane via sol-gel process: A novel microencapsulated phase-change material with enhanced thermal conductivity and performance. J Colloid Interf Sci. 2010;343:246-55.

[49] Yeh L. Review of heat transfer technologies in electronic equipment. Journal of Electronic Packaging. 1995;117:333.

[50] Patapoutian A, Peier AM, Story GM, Viswanath V. ThermoTRP channels and beyond: mechanisms of temperature sensation. Nature Reviews Neuroscience. 2003;4:529-39.

[51] Alawadhi EM, Amon CH. PCM thermal control unit for portable electronic devices: Experimental and numerical studies. Ieee $\mathrm{T}$ Compon Pack $\mathrm{T}$. 2003;26:116-25. 
[52] Hodes M, Weinstein RD, Pence SJ, Piccini JM, Manzione L, Chen C. Transient thermal management of a handset using phase change material (PCM). Journal of Electronic Packaging. 2002;124:419-26.

[53] Kandasamy R, Wang XQ, Mujunidar AS. Application of phase change materials in thermal management of electronics. Appl Therm Eng. 2007;27:2822-32.

[54] Wang XQ, Mujumdar AS, Yap C. Effect of orientation for phase change material (PCM)-based heat sinks for transient thermal management of electric components. Int Commun Heat Mass. 2007;34:801-8.

[55] Krishnan S, Garimella SV. Thermal management of transient power spikes in electronics - Phase change energy storage or copper heat sinks? Journal of Electronic Packaging. 2004;126:308-16.

[56] Krishnan S, Garimella SV, Kang SS. A novel hybrid heat sink using phase change materials for transient thermal management of electronics. Ieee $\mathrm{T}$ Compon Pack T. 2005;28:281-9.

[57] Nayak KC, Saha SK, Srinivasan K, Dutta P. A numerical model for heat sinks with phase change materials and thermal conductivity enhancers. Int $\mathrm{J}$ Heat Mass Tran. 2006;49:1833-44.

[58] Mahmoud S, Tang A, Toh C, Al-Dadah R, Soo SL. Experimental investigation of inserts configurations and PCM type on the thermal performance of PCM based heat sinks. Appl Energ. 2013.

[59] Dubovsky V, Barzilay G, Granot G, Ziskind G, Letan R. Study of Pcm-Based Pin-Fin Heat Sinks. Ht2009: Proceedings of the Asme Summer Heat Transfer Conference 2009, Vol 1. 2009:857-63.

[60] Baby R, Balaji C. Thermal management of electronics using phase change material based pin fin heat sinks. Journal of Physics: Conference Series: IOP Publishing; 2012. p. 012134.

[61] Baby R, Balaji C. Thermal optimization of PCM based pin fin heat sinks: An experimental study. Appl Therm Eng. 2013;54:65-77.

[62] Qu ZG, Li WQ, Wang JL, Tao WQ. Passive thermal management using metal foam saturated with phase change material in a heat sink. Int Commun Heat Mass. 2012;39:1546-9.

[63] Sanusi O, Fleischer A, Weinstein R. An Investigation into the Solidification of Nano-Enhanced Phase Change Material for Transient Thermal Management of Electronics. Intersoc C Thermal T. 2010.

[64] Yin HB, Gao XN, Ding J, Zhang ZG, Fang YT. Thermal management of electronic components with thermal adaptation composite material. Appl Energ. 2010;87:3784-91.

[65] Alawadhi EM. Thermal Management of Blocks in a Channel Using Phase Change Material. Ieee T Compon Pack T. 2009;32:89-99.

[66] Wang S, Baldea M. Storage-enhanced thermal management for mobile devices. American Control Conference (ACC), 20132013. p. 5344-9.

[67] Weng Y-C, Cho H-P, Chang C-C, Chen S-L. Heat pipe with PCM for electronic cooling. Appl Energ. 2011;88:1825-33.

[68] Shaikh S, Lafdi K. C/C composite, carbon nanotube and paraffin wax hybrid 
systems for the thermal control of pulsed power in electronics. Carbon. 2010;48:813-24.

[69] Yaquinto M, Wirtz R. Transition Temperature Stratified Thermal Energy Storage Systems Applied to on-Demand Cooling of High Power-Density Hand-Held Electronics. Ipack 2009: Proceedings of the Asme Interpack Conference 2009, Vol 2. 2010:887-96.

[70] Vetter J, Novak P, Wagner MR, Veit C, Moller KC, Besenhard JO, et al. Ageing mechanisms in lithium-ion batteries. Journal of Power Sources. 2005;147:269-81.

[71] Safari M, Morcrette M, Teyssot A, Delacourt C. Multimodal Physics-Based Aging Model for Life Prediction of Li-Ion Batteries. Journal of the Electrochemical Society. 2009;156:A145-A53.

[72] Broussely M, Biensan P, Bonhomme F, Blanchard P, Herreyre S, Nechev K, et al. Main aging mechanisms in Li ion batteries. Journal of Power Sources. 2005;146:90-6. [73] Dubarry M, Liaw BY, Chen M-S, Chyan S-S, Han K-C, Sie W-T, et al. Identifying battery aging mechanisms in large format $\mathrm{Li}$ ion cells. Journal of Power Sources. 2011;196:3420-5.

[74] Wang J, Liu P, Hicks-Garner J, Sherman E, Soukiazian S, Verbrugge M, et al. Cycle-life model for graphite-LiFePO4 cells. Journal of Power Sources. 2011;196:3942-8.

[75] Zhang SS, Xu K, Jow TR. The low temperature performance of Li-ion batteries. Journal of Power Sources. 2003;115:137-40.

[76] Zhang SS, Xu K, Jow TR. Electrochemical impedance study on the low temperature of Li-ion batteries. Electrochim Acta. 2004;49:1057-61.

[77] Zhang YC, Wang CY, Tang XD. Cycling degradation of an automotive LiFePO4 lithium-ion battery. Journal of Power Sources. 2011;196:1513-20.

[78] Wang Q, Ping P, Zhao X, Chu G, Sun J, Chen C. Thermal runaway caused fire and explosion of lithium ion battery. Journal of Power Sources. 2012;208:210-24.

[79] Liu P, Wang J, Hicks-Garner J, Sherman E, Soukiazian S, Verbrugge M, et al. Aging Mechanisms of LiFePO4 Batteries Deduced by Electrochemical and Structural Analyses. Journal of the Electrochemical Society. 2010;157:A499-A507.

[80] Amine K, Liu J, Belharouak I. High-temperature storage and cycling of C-LiFePO4/graphite Li-ion cells. Electrochem Commun. 2005;7:669-73.

[81] Wright RB, Christophersen JP, Motloch CG, Belt JR, Ho CD, Battaglia VS, et al. Power fade and capacity fade resulting from cycle-life testing of Advanced Technology Development Program lithium-ion batteries. Journal of Power Sources. 2003;119:865-9.

[82] Shim J, Kostecki R, Richardson T, Song X, Striebel KA. Electrochemical analysis for cycle performance and capacity fading of a lithium-ion battery cycled at elevated temperature. Journal of Power Sources. 2002;112:222-30.

[83] Ramadass P, Haran B, White R, Popov BN. Capacity fade of Sony 18650 cells cycled at elevated temperatures Part I. Cycling performance. Journal of Power Sources. 2002;112:606-13.

[84] Ramadass P, Haran B, White R, Popov BN. Capacity fade of Sony 18650 cells cycled at elevated temperatures Part II. Capacity fade analysis. Journal of Power 
Sources. 2002;112:614-20.

[85] Kim J-H, Woo SC, Park M-S, Kim KJ, Yim T, Kim J-S, et al. Capacity fading mechanism of LiFePO4-based lithium secondary batteries for stationary energy storage. Journal of Power Sources. 2013;229:190-7.

[86] Väyrynen A, Salminen J. Lithium ion battery production. The Journal of Chemical Thermodynamics. 2012;46:80-5.

[87] Pesaran AA. Battery thermal models for hybrid vehicle simulations. Journal of Power Sources. 2002;110:377-82.

[88] Karimi G, Li X. Thermal management of lithium-ion batteries for electric vehicles. Int J Energ Res. 2012:n/a-n/a.

[89] Al Hallaj S, Selman JR. A novel thermal management system for electric vehicle batteries using phase-change material. Journal of the Electrochemical Society. 2000;147:3231-6.

[90] Ramandi MY, Dincer I, Naterer GF. Heat transfer and thermal management of electric vehicle batteries with phase change materials. Heat Mass Transfer. 2011;47:777-88.

[91] Al-Hallaj S, Selman JR. Thermal modeling of secondary lithium batteries for electric vehicle/hybrid electric vehicle applications. Journal of Power Sources. 2002;110:341-8.

[92] Al-Hallaj S, Khateeb SA, Amiruddin S, Farid M, Selman JR. Thermal management of Li-ion battery with phase change material for electric scooters: experimental validation. Journal of Power Sources. 2005;142:345-53.

[93] Duan X, Naterer GF. Heat transfer in phase change materials for thermal management of electric vehicle battery modules. Int $\mathrm{J}$ Heat Mass Tran. 2010;53:5176-82.

[94] Sabbah R, Kizilel R, Selman JR, Al-Hallaj S. Active (air-cooled) vs. passive (phase change material) thermal management of high power lithium-ion packs: Limitation of temperature rise and uniformity of temperature distribution. Journal of Power Sources. 2008;182:630-8.

[95] Somasundaram K, Birgersson E, Mujumdar AS. Thermal-electrochemical model for passive thermal management of a spiral-wound lithium-ion battery. Journal of Power Sources. 2012;203:84-96.

[96] Rao Z, Wang S, Zhang G. Simulation and experiment of thermal energy management with phase change material for ageing $\mathrm{LiFePO} 4$ power battery. Energ Convers Manage. 2011;52:3408-14.

[97] Kizilel R, Lateef A, Sabbah R, Farid MM, Selman JR, Al-Hallaj S. Passive control of temperature excursion and uniformity in high-energy Li-ion battery packs at high current and ambient temperature. Journal of Power Sources. 2008;183:370-5.

[98] Al-Hallaj S, Kizilel R, Lateef A, Sabbah R, Farid M, Selman JR. Passive thermal management using phase change material (PCM) for EV and HEV Li-ion batteries. 2005 IEEE Vehicle Power and Propulsion Conference (VPPC). 2005:376-80.

[99] Khateeb SA, Farid MM, Selman JR, Al-Hallaj S. Design and simulation of a lithium-ion battery with a phase change material thermal management system for an electric scooter. Journal of Power Sources. 2004;128:292-307. 
[100] Mazer JA. Solar cells: an introduction to crystalline photovoltaic technology: Kluwer Academic Publishers; 1997.

[101] Radziemska E, Klugmann E. Thermally affected parameters of the current-voltage characteristics of silicon photocell. Energ Convers Manage. 2002;43:1889-900.

[102] Jiang J-A, Wang J-C, Kuo K-C, Su Y-L, Shieh J-C, Chou J-J. Analysis of the junction temperature and thermal characteristics of photovoltaic modules under various operation conditions. Energy. 2012;44:292-301.

[103] Radziemska E. The effect of temperature on the power drop in crystalline silicon solar cells. Renewable Energy. 2003;28:1-12.

[104] Weakliem HA, Redfield D. Temperature dependence of the optical properties of silicon. Journal of Applied Physics. 1979;50:1491-3.

[105] Huang MJ, Eames PC, Norton B. Thermal regulation of building-integrated photovoltaics using phase change materials. Int J Heat Mass Tran. 2004;47:2715-33.

[106] Biwole PH, Eclache P, Kuznik F. Phase-change materials to improve solar panel's performance. Energ Buildings. 2013;62:59-67.

[107] Hasan A, McCormack SJ, Huang MJ, Norton B. Evaluation of phase change materials for thermal regulation enhancement of building integrated photovoltaics. Sol Energy. 2010;84:1601-12.

[108] Maiti S, Banerjee S, Vyas K, Patel P, Ghosh PK. Self regulation of photovoltaic module temperature in V-trough using a metal-wax composite phase change matrix. Sol Energy. 2011;85:1805-16.

[109] Tanuwijava A, Ho C, Lai C-M, Huang C-Y. Numerical Investigation of the Thermal Management Performance of MEPCM Modules for PV Applications. Energies. 2013;6:3922-36.

[110] Huang MJ, Eames PC, Norton B. Phase change materials for limiting temperature rise in building integrated photovoltaics. Sol Energy. 2006;80:1121-30.

[111] Huang MJ, Eames PC, Norton B, Hewitt NJ. Natural convection in an internally finned phase change material heat sink for the thermal management of photovoltaics. Sol Energ Mat Sol C. 2011;95:1598-603.

[112] Huang MJ. The effect of using two PCMs on the thermal regulation performance of BIPV systems. Sol Energ Mat Sol C. 2011;95:957-63.

[113] Malvi CS, Dixon-Hardy DW, Crook R. Energy balance model of combined photovoltaic solar-thermal system incorporating phase change material. Sol Energy. 2011;85:1440-6. 


\section{Figure captions}

Figure 1 Schematic of the PCM-based thermal control unit in a prototype of a Technical Information Assistance (TIA).

Figure 2 (a) Six types of heat sink designs tested, and (b) dimensions of honeycomb insert.

Figure 3 Thermal management performances of (a) Heat sinks with different dissipation modes and (b) heat sinks with copper foams varied with porosity and pore density.

Figure 4 (a) Comparisons of heat storage \& release curves between pure paraffin and paraffin/EG composites, and (b) temperature variations versus time among systems with/without PCMs.

Figure 5 Multiple PCMs in series thermal control composites with (a) different PCMs and (b) similar PCMs

Figure 6 Schematic of a PCM-based BTMS for commercial 18650 batteries : (a) PCM filled closed box, (b) Li-ion cells and (c) battery module.

Figure 7 Schematic of the configurations of BTMS with (a) single-PCM shell and (b) double-PCM shell for a prismatic battery.

Figure 8 Curves of average cell temperature for different BTMSs at a discharge rate of $6.67 \mathrm{C}:(\mathrm{a}) \mathrm{T}_{\mathrm{amb}}=25^{\circ} \mathrm{C}$ and (b) $\mathrm{Tamb}=45^{\circ} \mathrm{C}$.

Figure 9 Temperature curves of the battery with thermal management of (a) single-layer PCMs and (b) double-layer PCMs.

Figure 10 Temperature profiles of two adjacent cells under different thermal 
management methods. $\left(\mathrm{Tamb}=40{ }^{\circ} \mathrm{C}\right.$, Discharge rate $=6.67 \mathrm{C}, 50 \mathrm{~A} /$ module $)$ : (a) Cooled by the forced air convection and (b) cooled by the PCM

Figure 11 Capacity fade of battery modules with/without PCM.

Figure 12 The predicted electrical conversion efficiencies for the base case flat aluminum plate and PV/PCM test system.

Figure 13 Structures of PV/PCM systems with metal cells for double-layer PCMs..

Figure 14 Comparison of front surface temperatures evolution predicted for three cases of PV/PCM systems with triangle cells at an insolation of $1000 \mathrm{~W} \mathrm{m-2}$ and an ambient temperature of $20{ }^{\circ} \mathrm{C}$.

Figure 15 Illustration showing panel construction from: (a) a plan view, (b) a cross-sectional view and (c) Illustration of a typical installation for an active closed-loop system. 


\section{Table captions}

Table 1 . Summary of methods in enhancing PCM thermal conductivity.

Table 1 . Summary of studies on capacity and power fade of batteries.

Table 3 . Thermal properties of PCMs. 

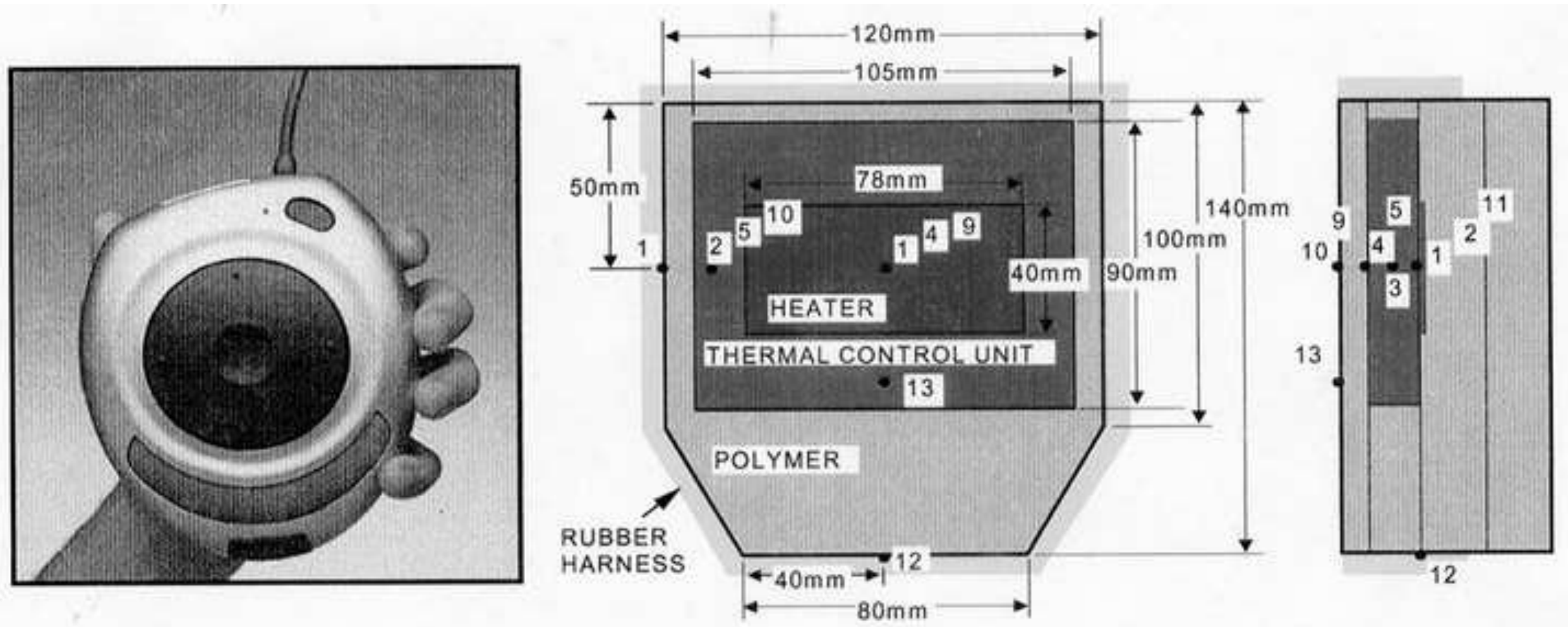


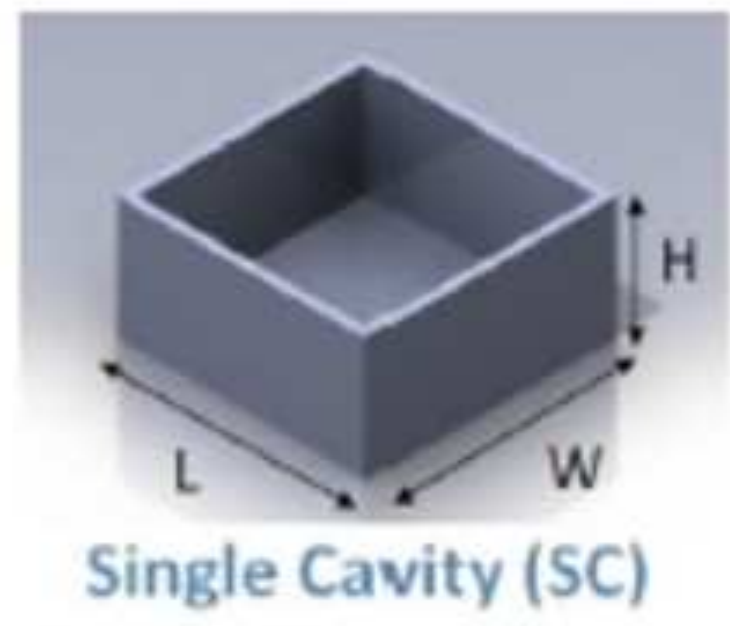

Single Cavity (SC)

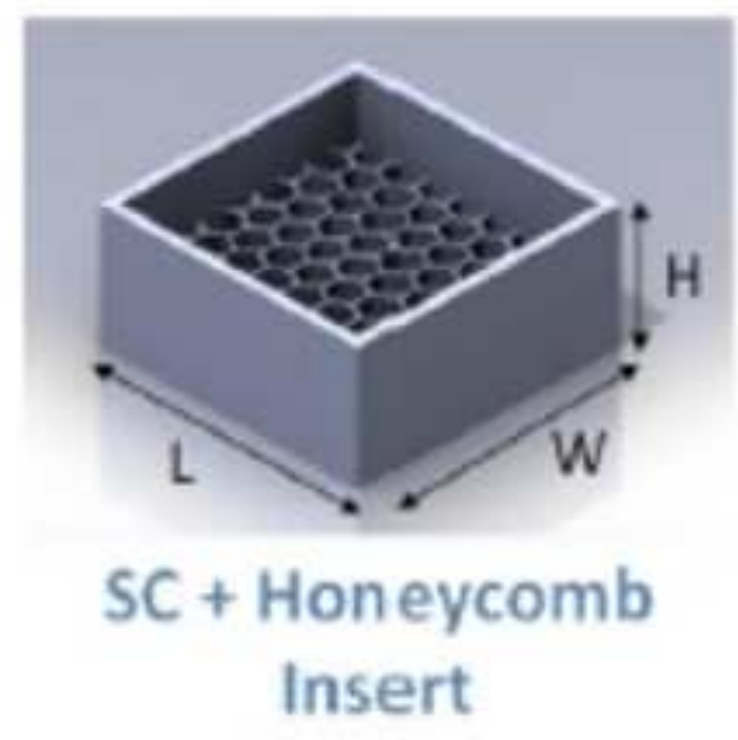

$\mathrm{SC}+$ Hon eycomb Insert
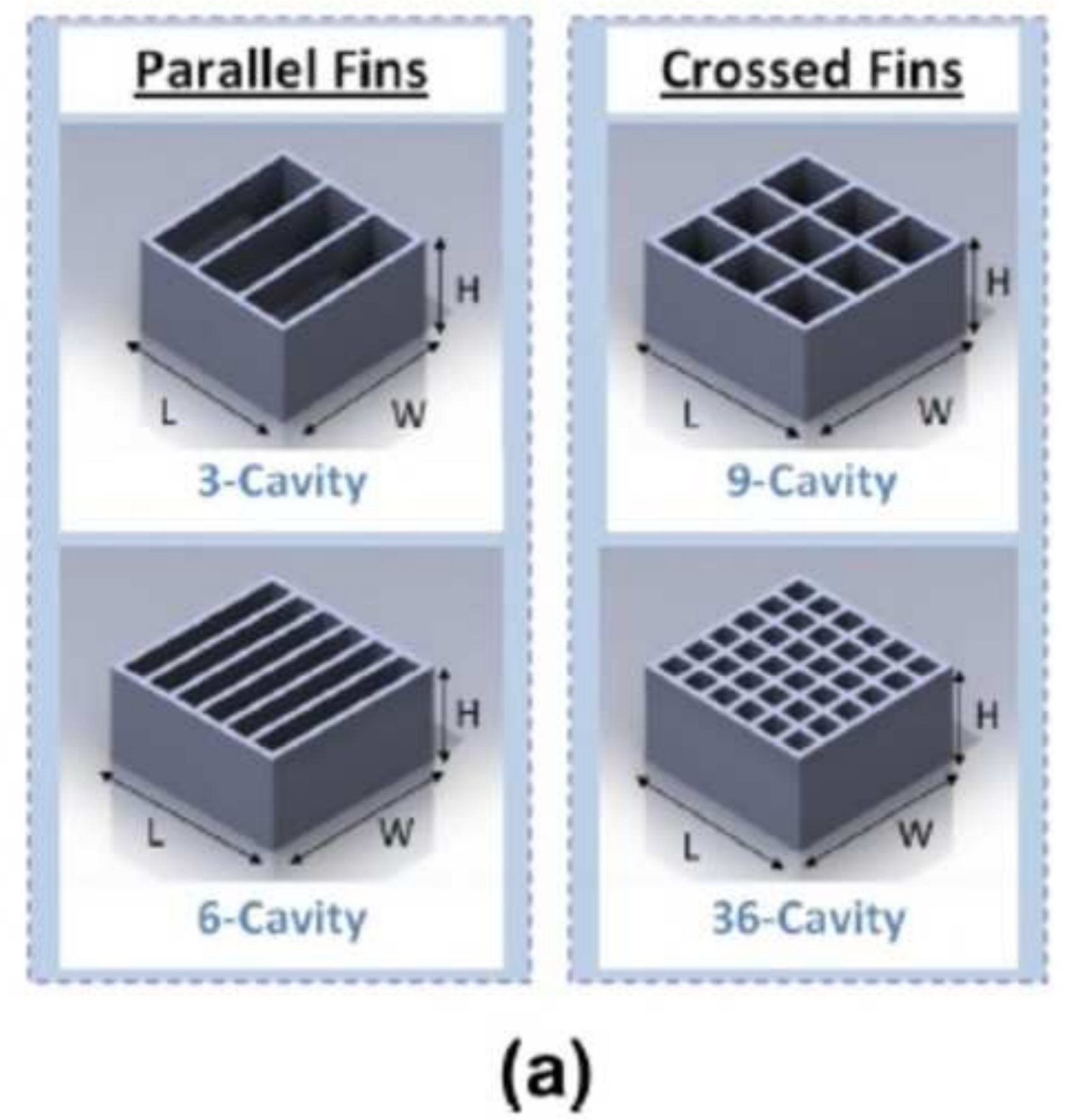

(a)

\section{Crossed Fins}

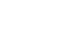

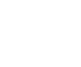


Figure 2(b)

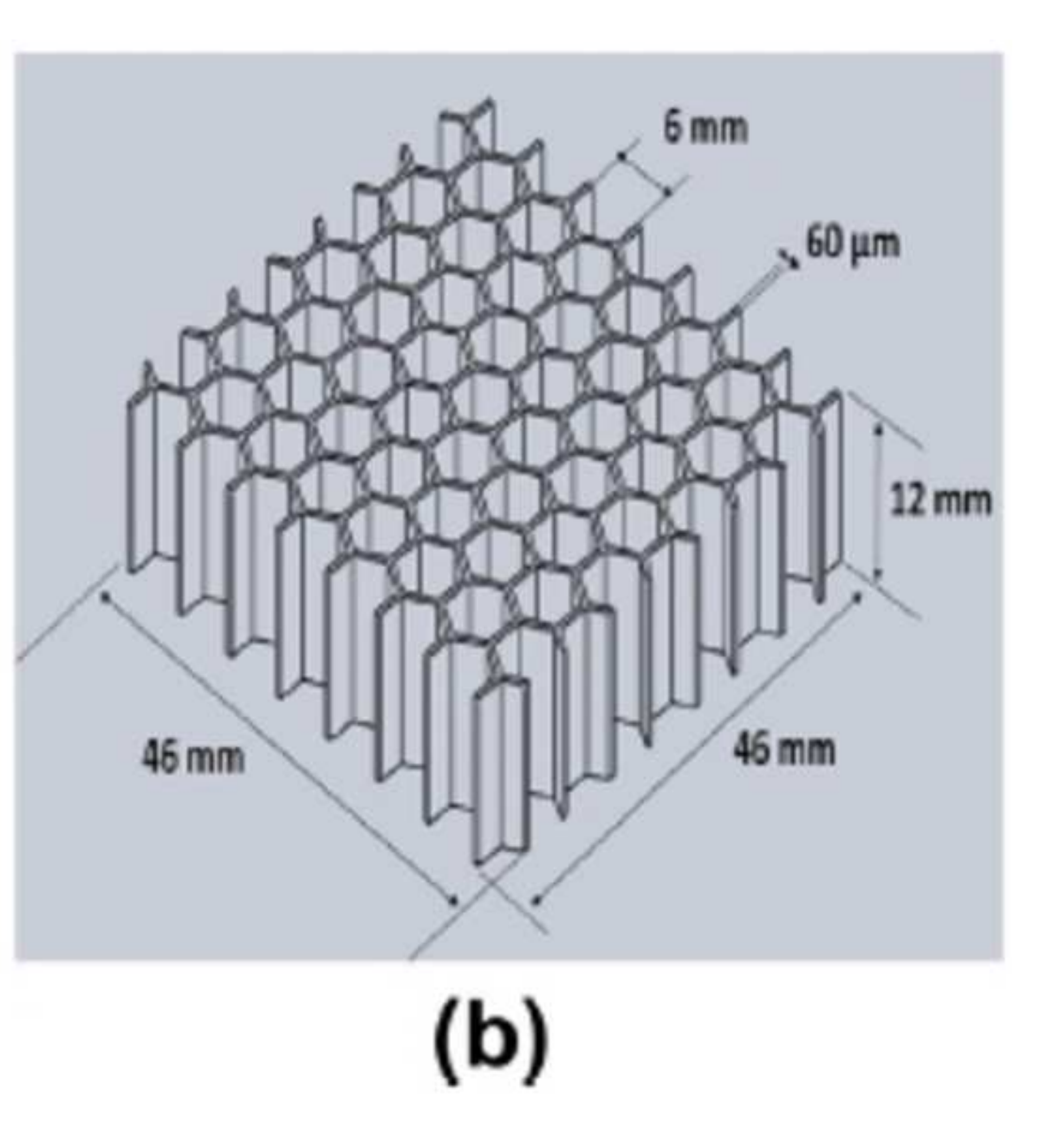

\section{(b)}

Figu
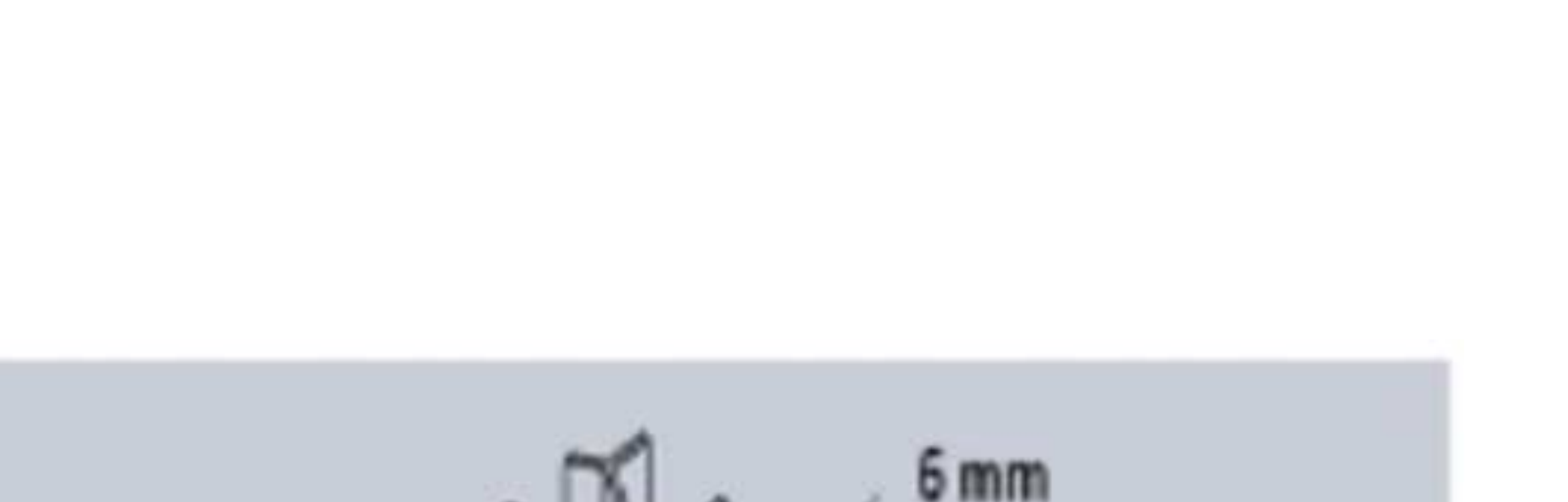

te

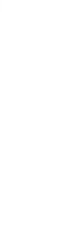

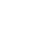

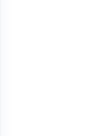


(a) 90

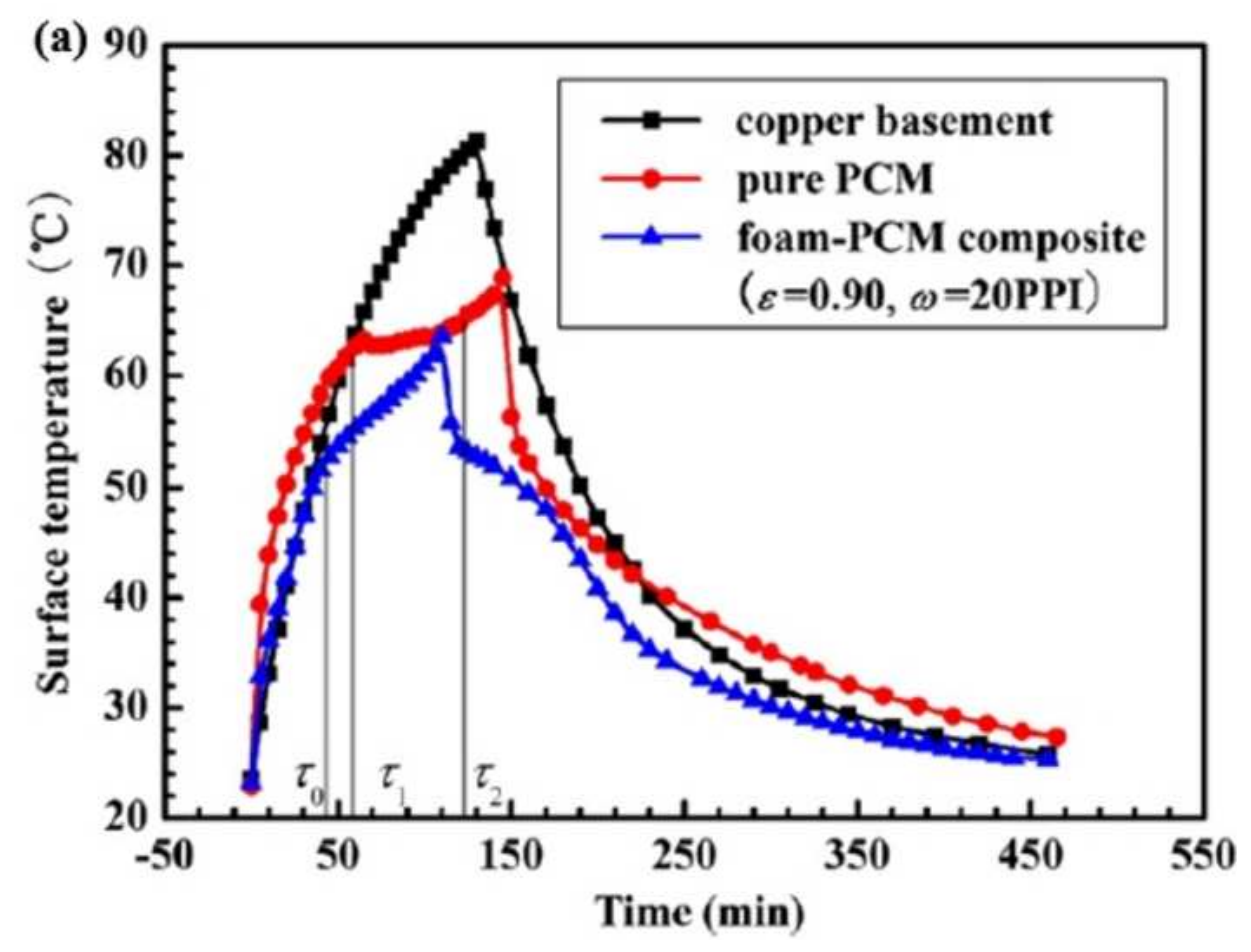


(b) 80

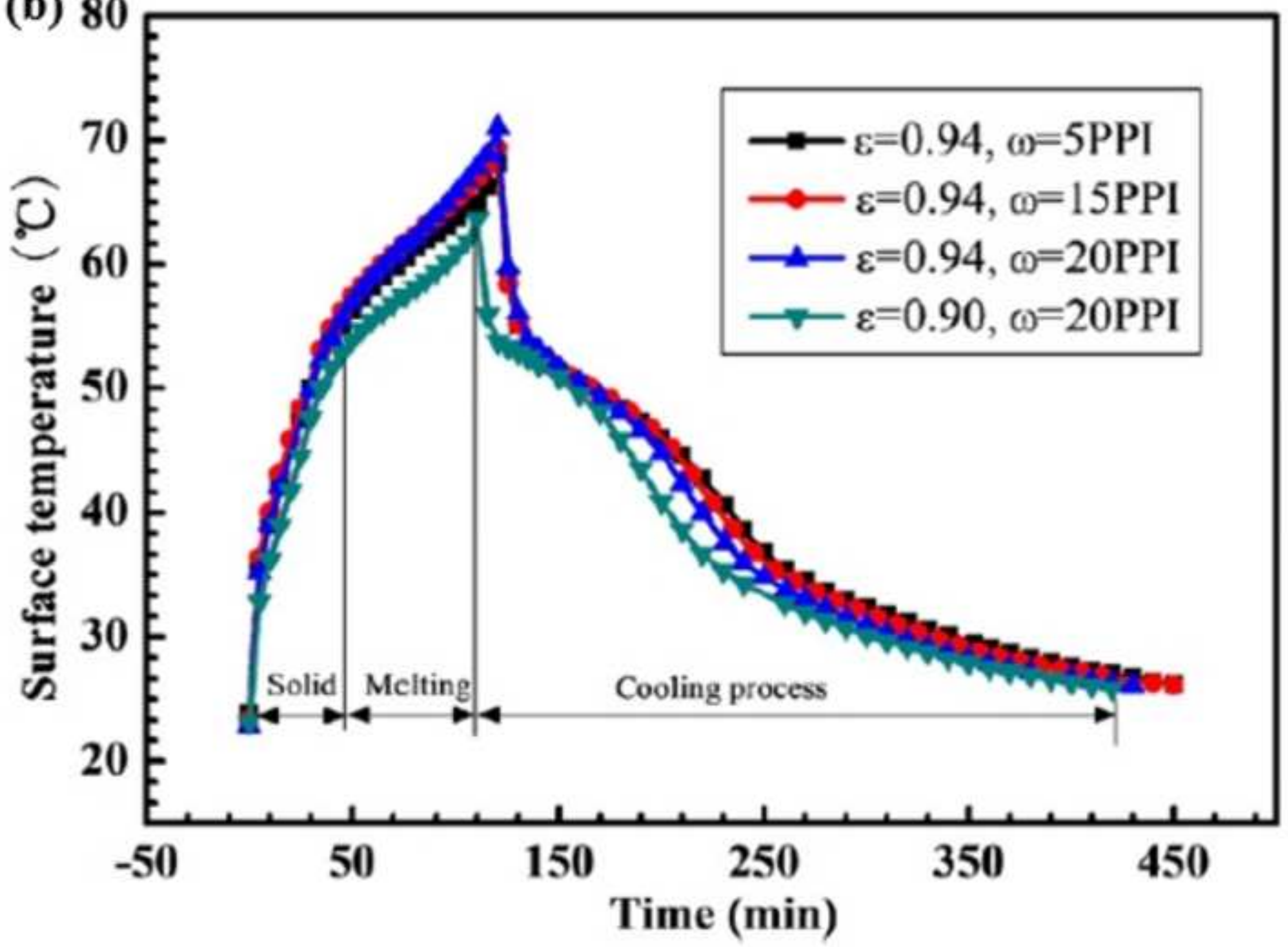

\section{Time (min)}




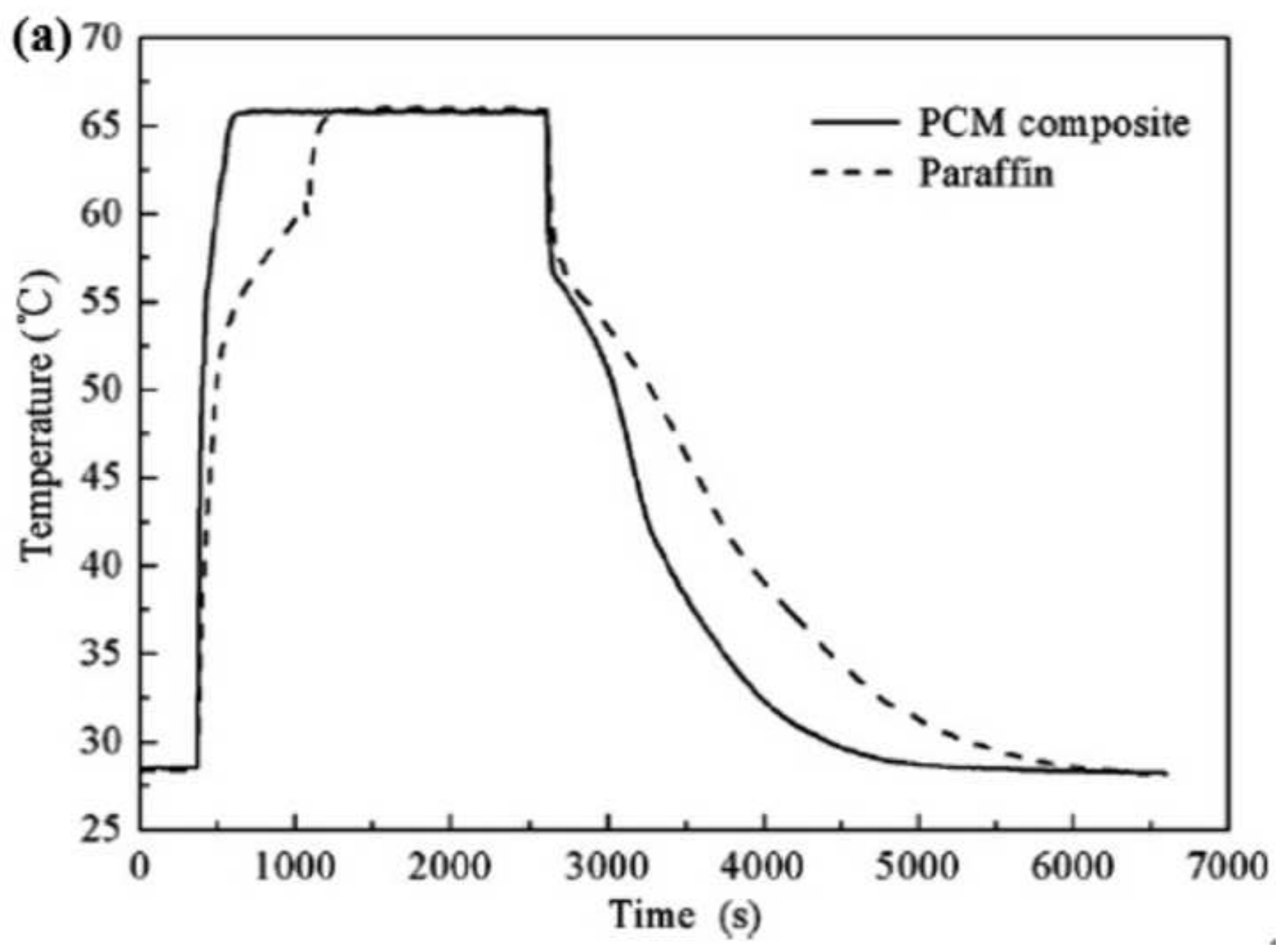



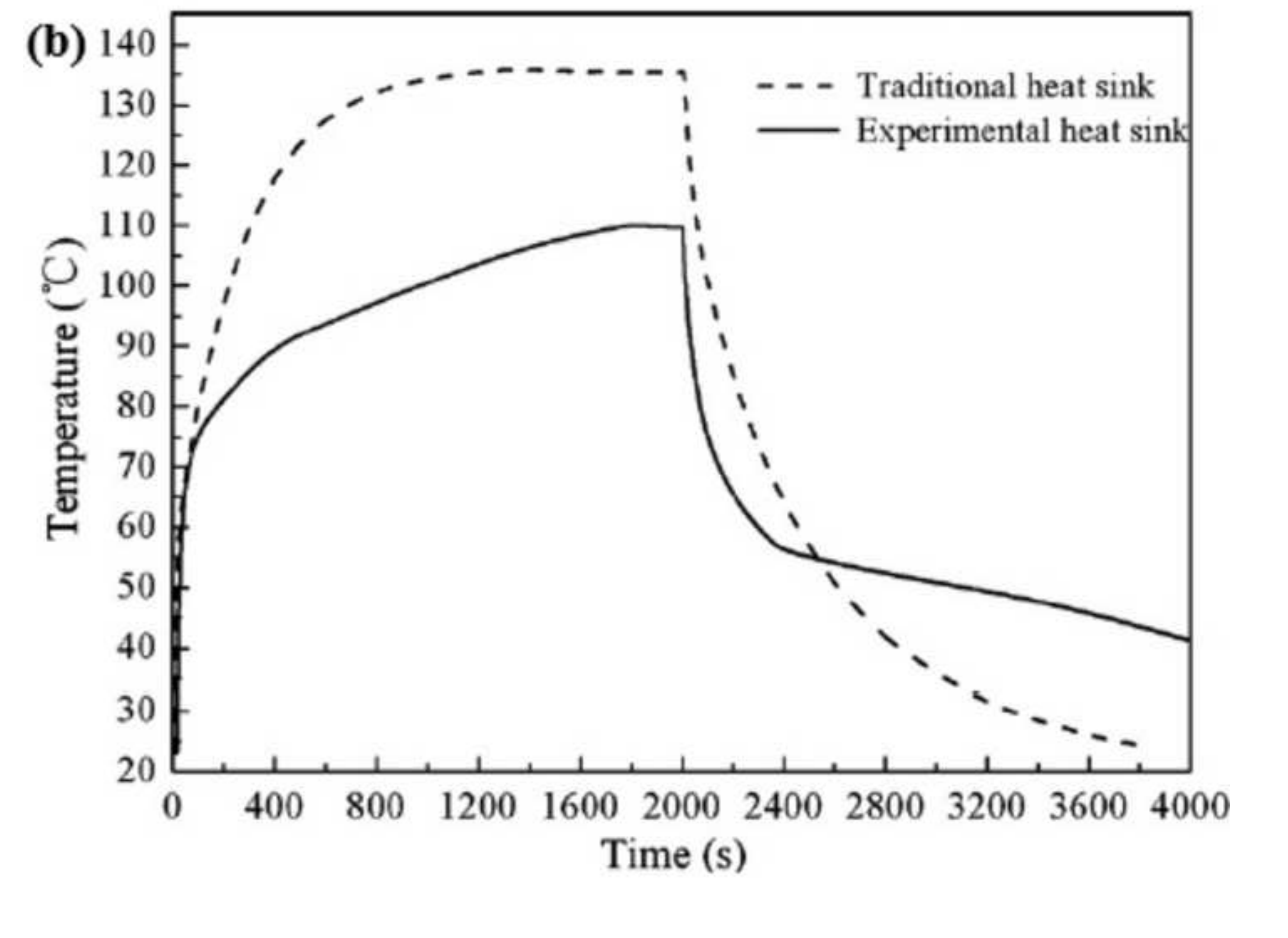
(b)

Plexiglass plate

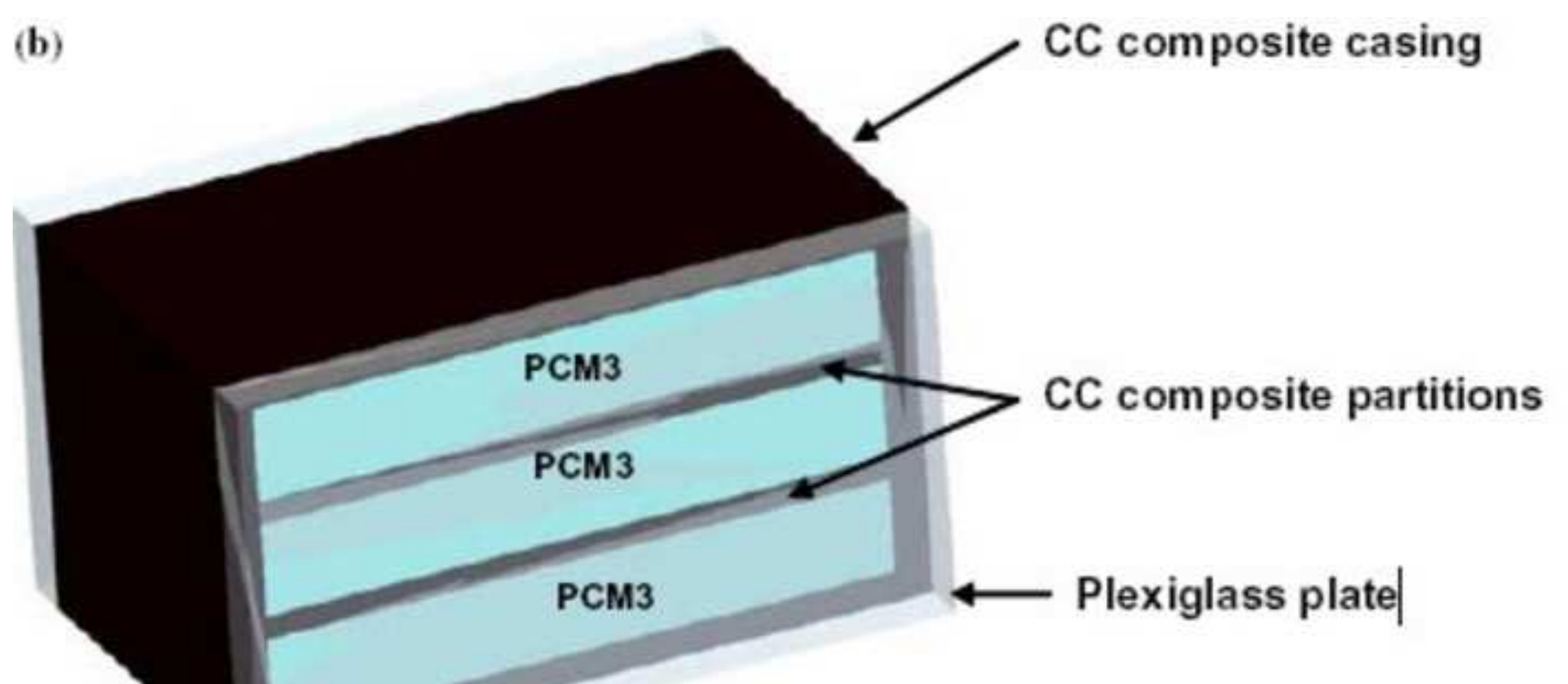

CC composite casing

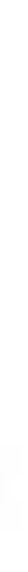




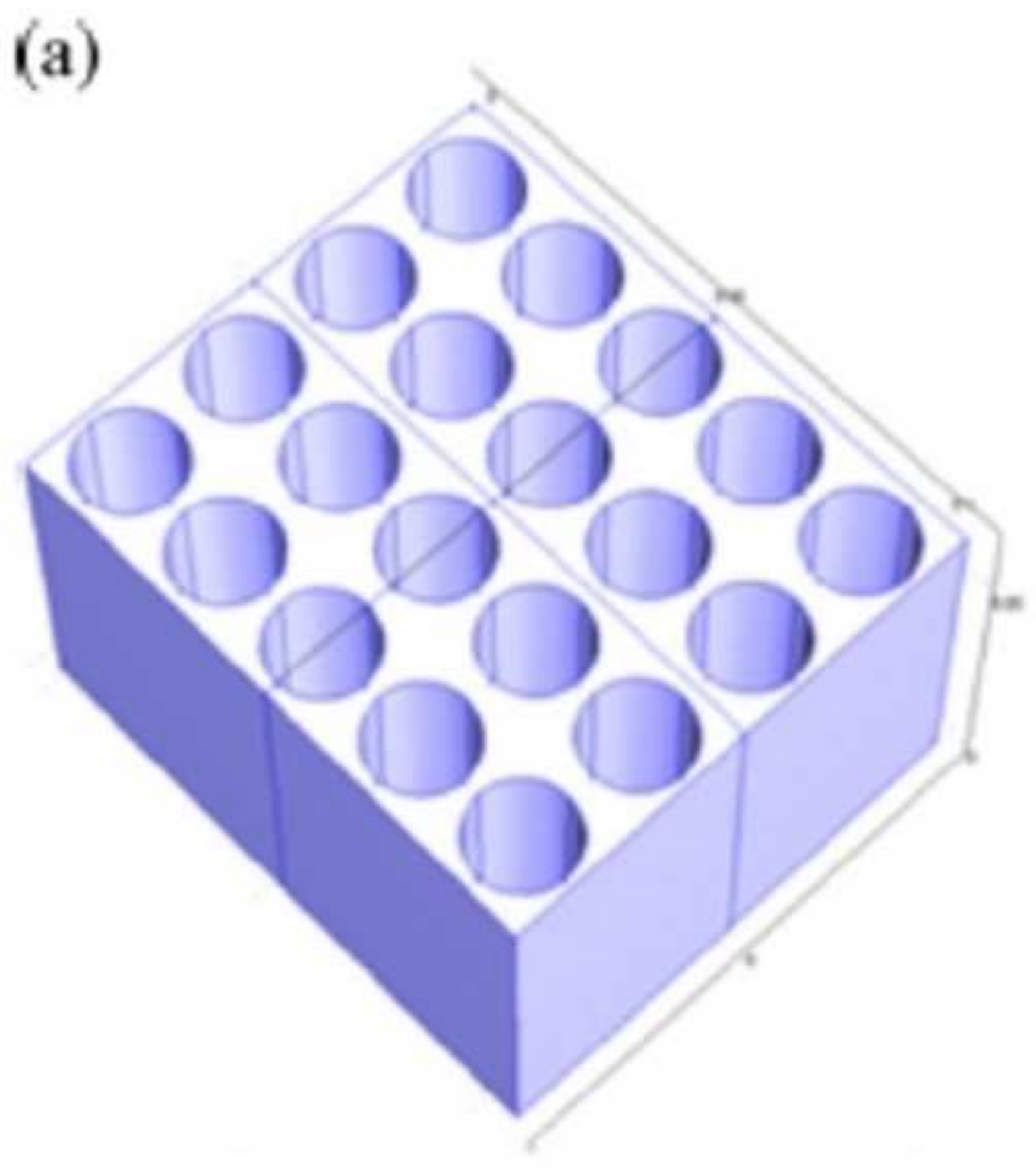

Figure 6(a)

\section{Fire $6(a)$}

(a)

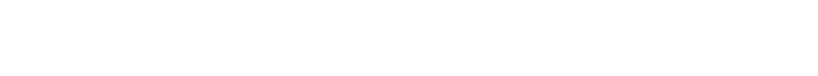




\section{(b)}

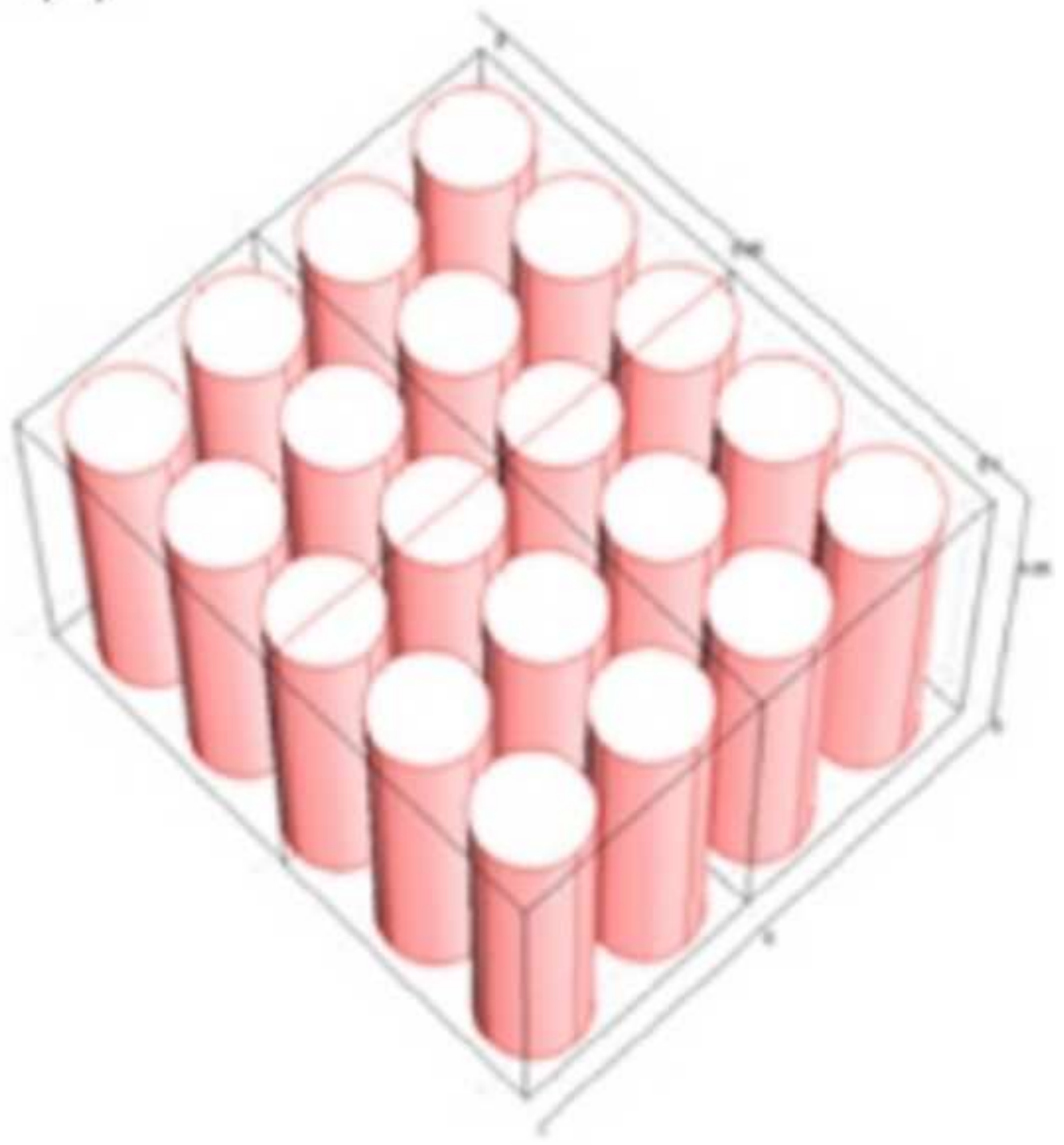


Figure $6(c)$

(c)

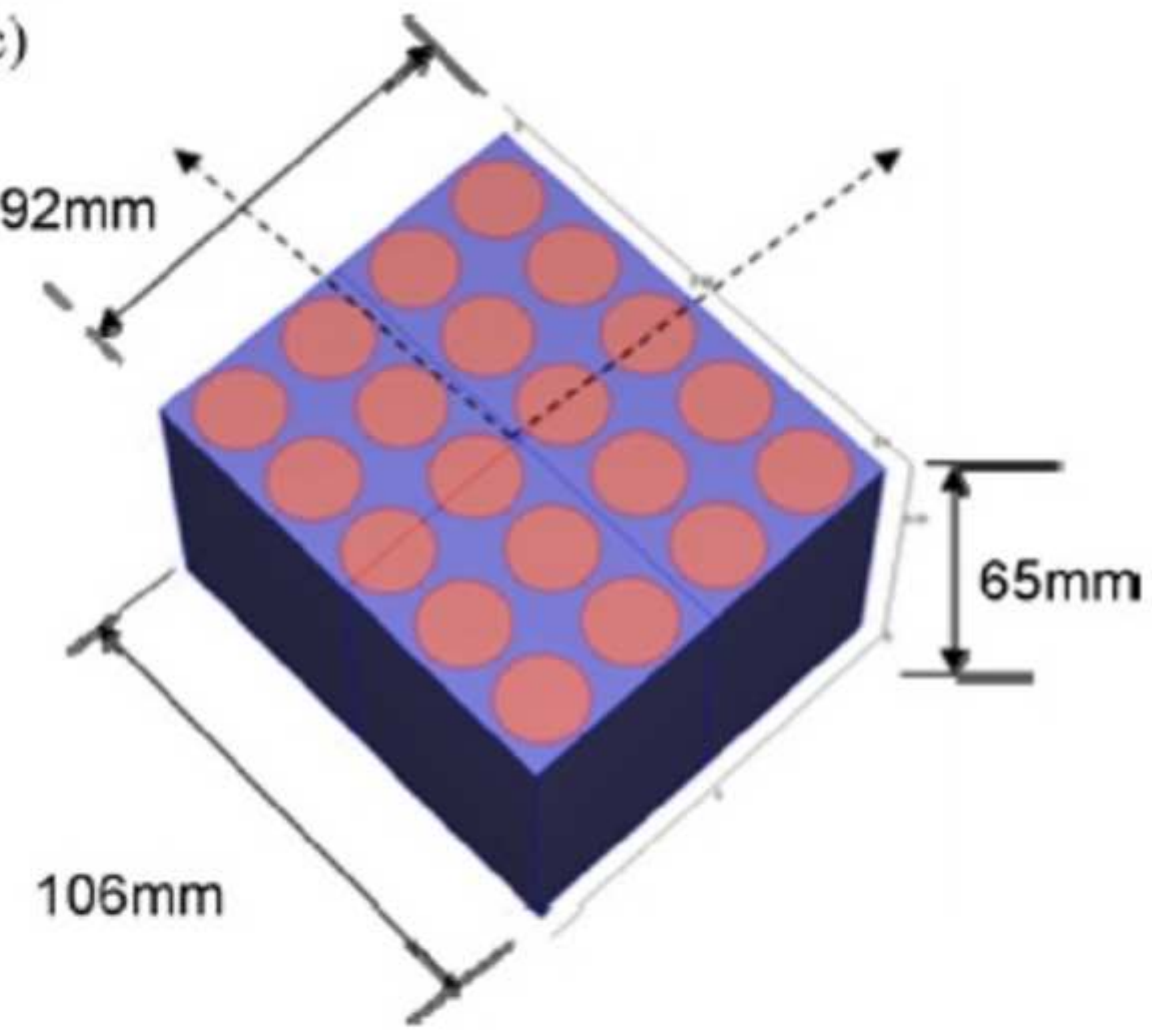



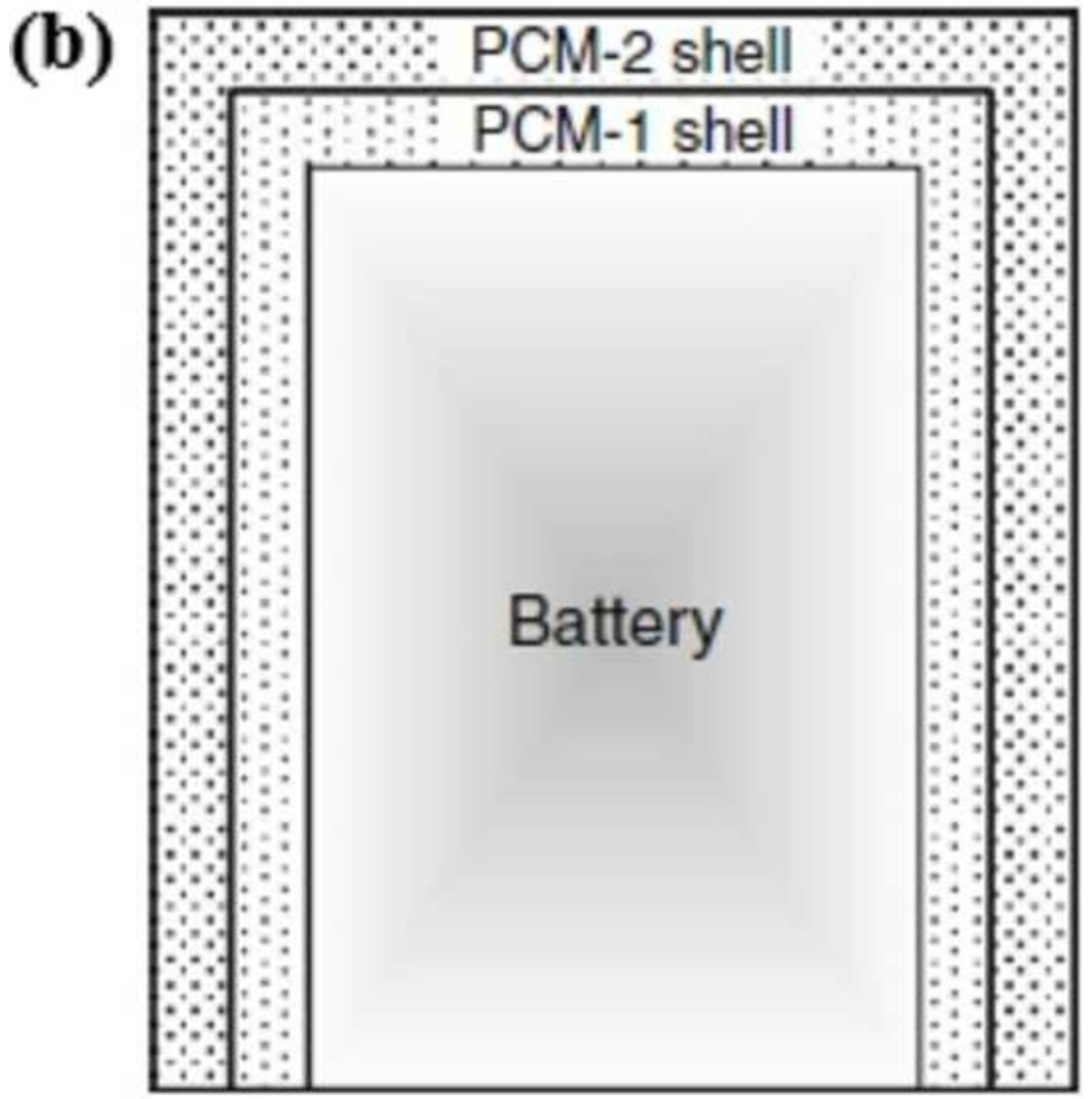

Figure $7(b)$ 

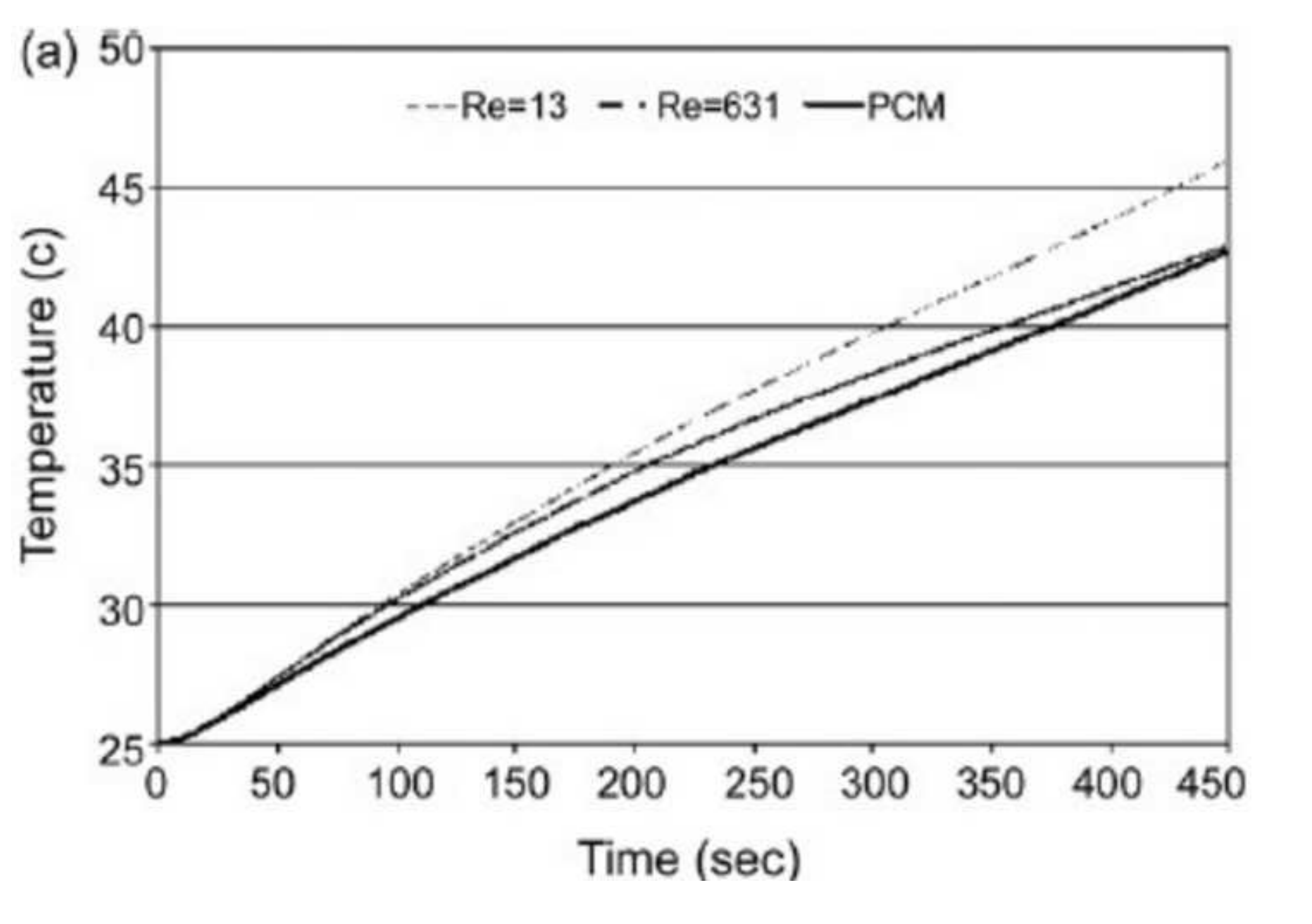

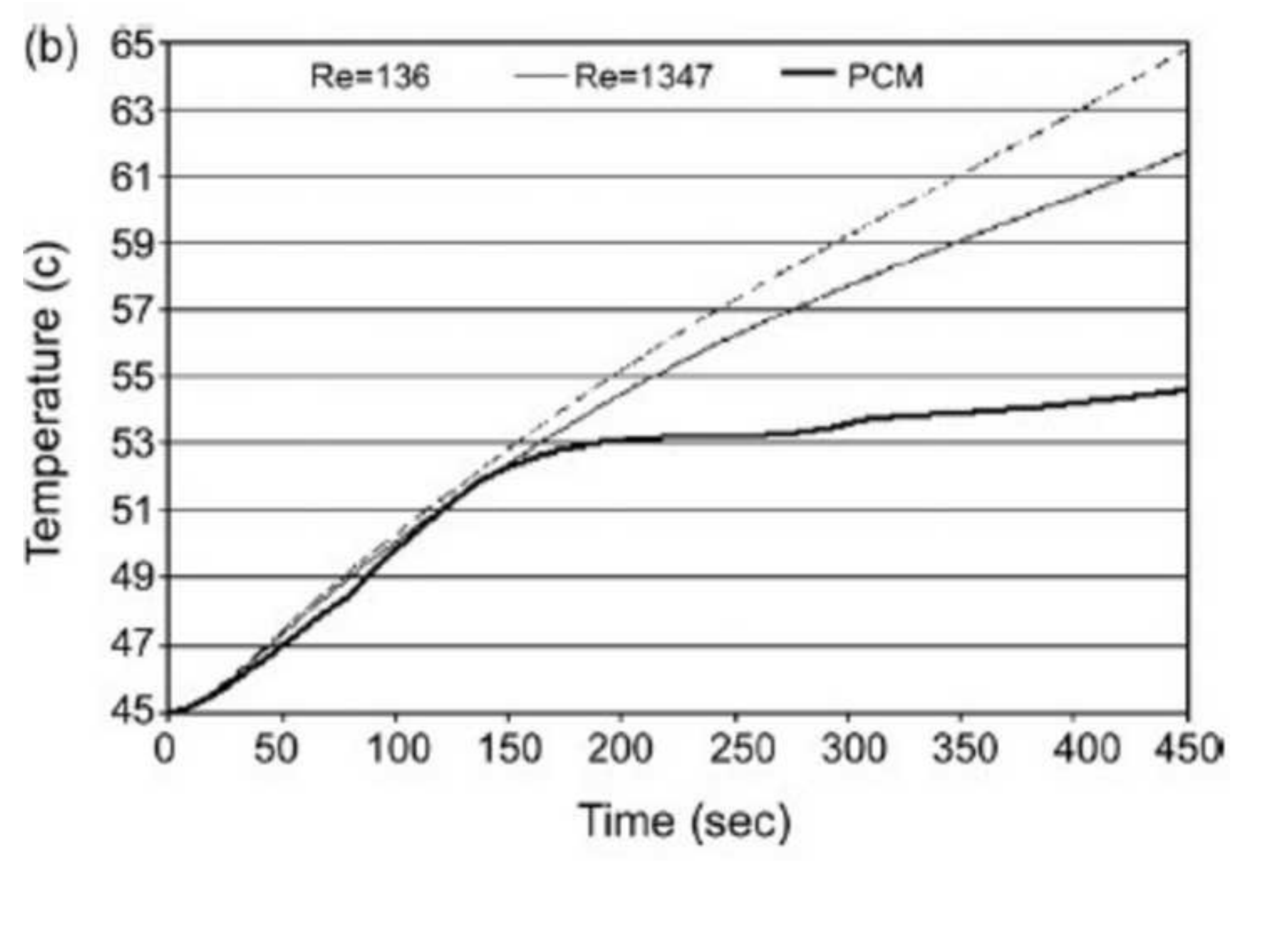


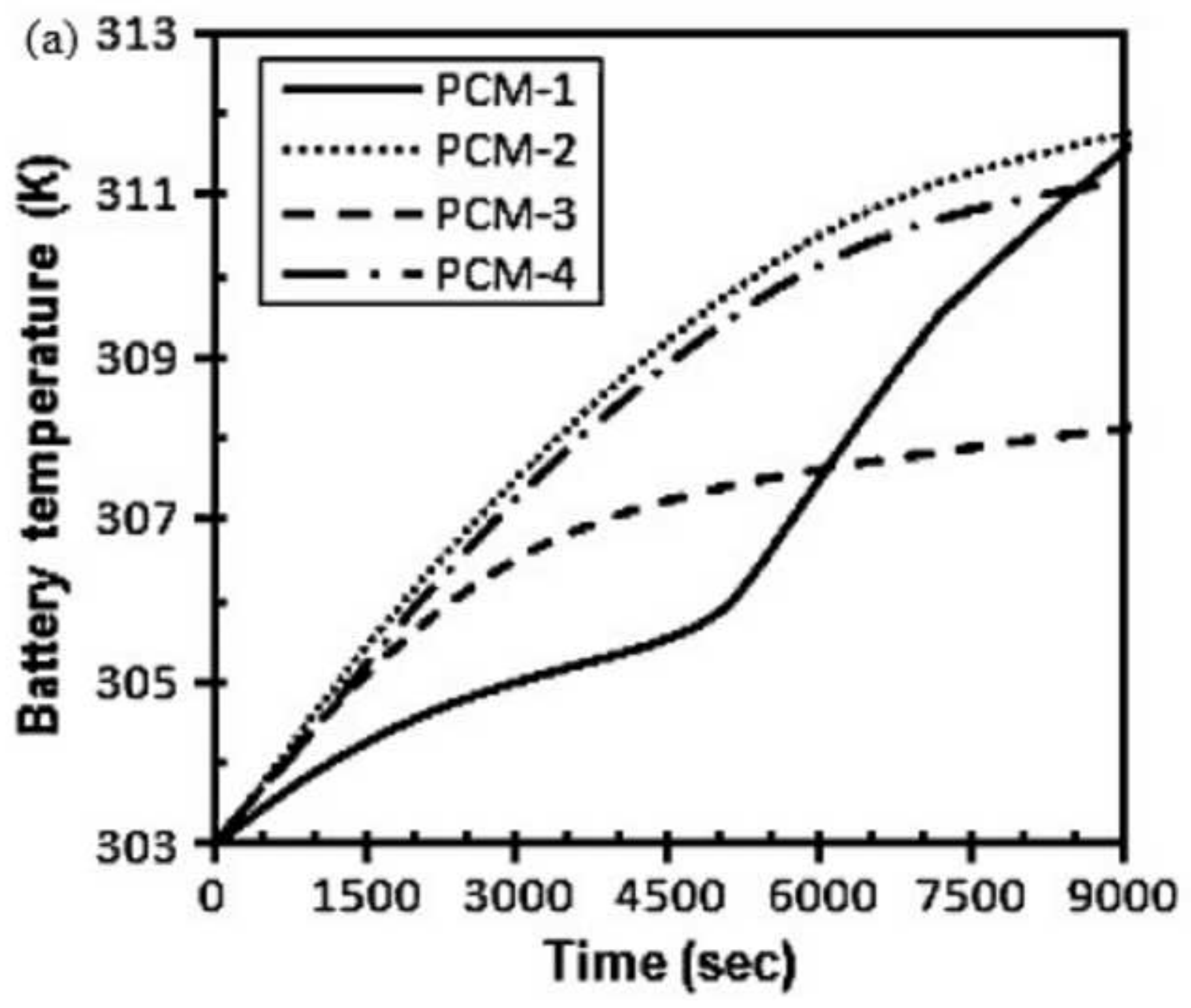


(a)

Air Cooling

$\operatorname{Max} 60.984$

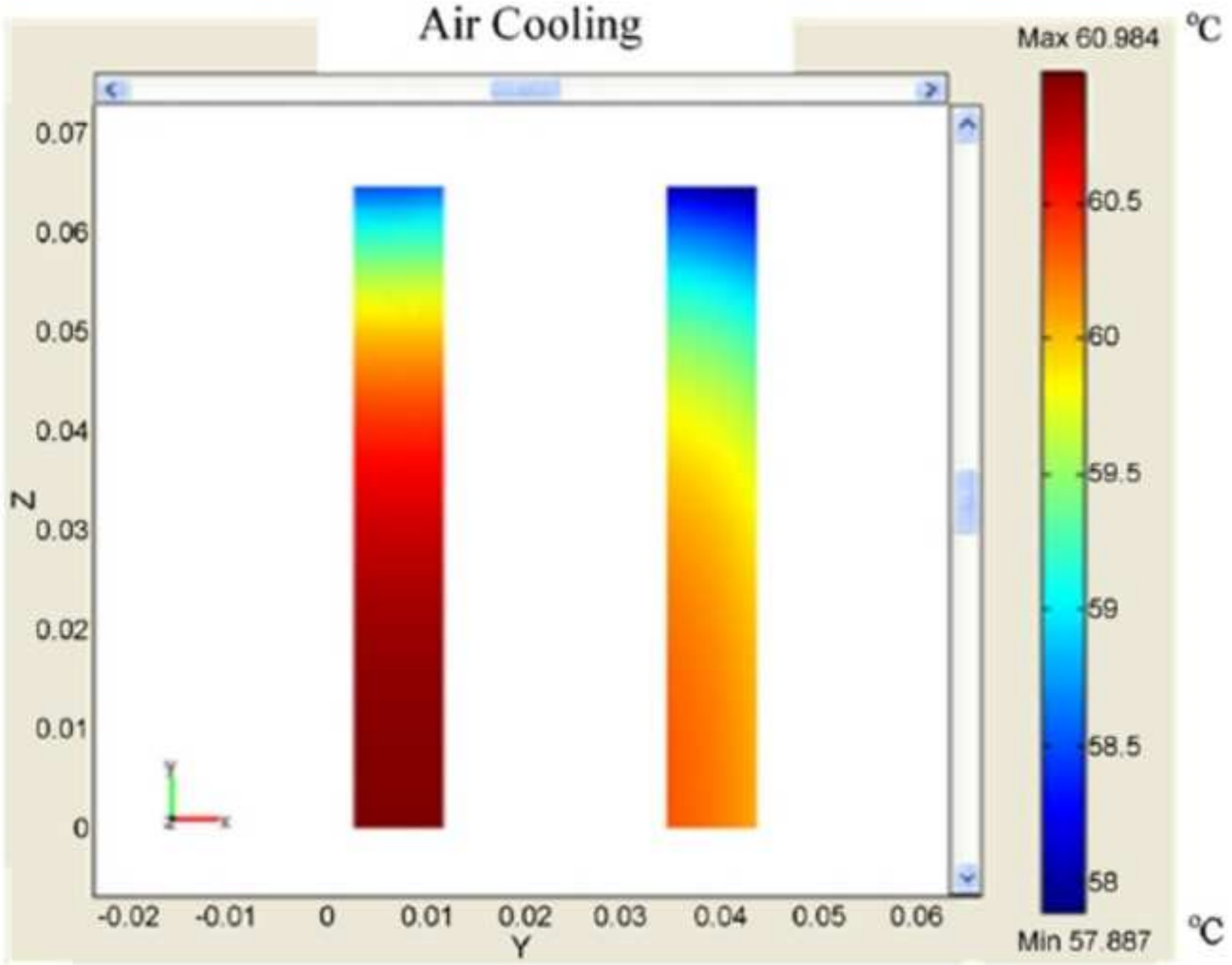


(b)

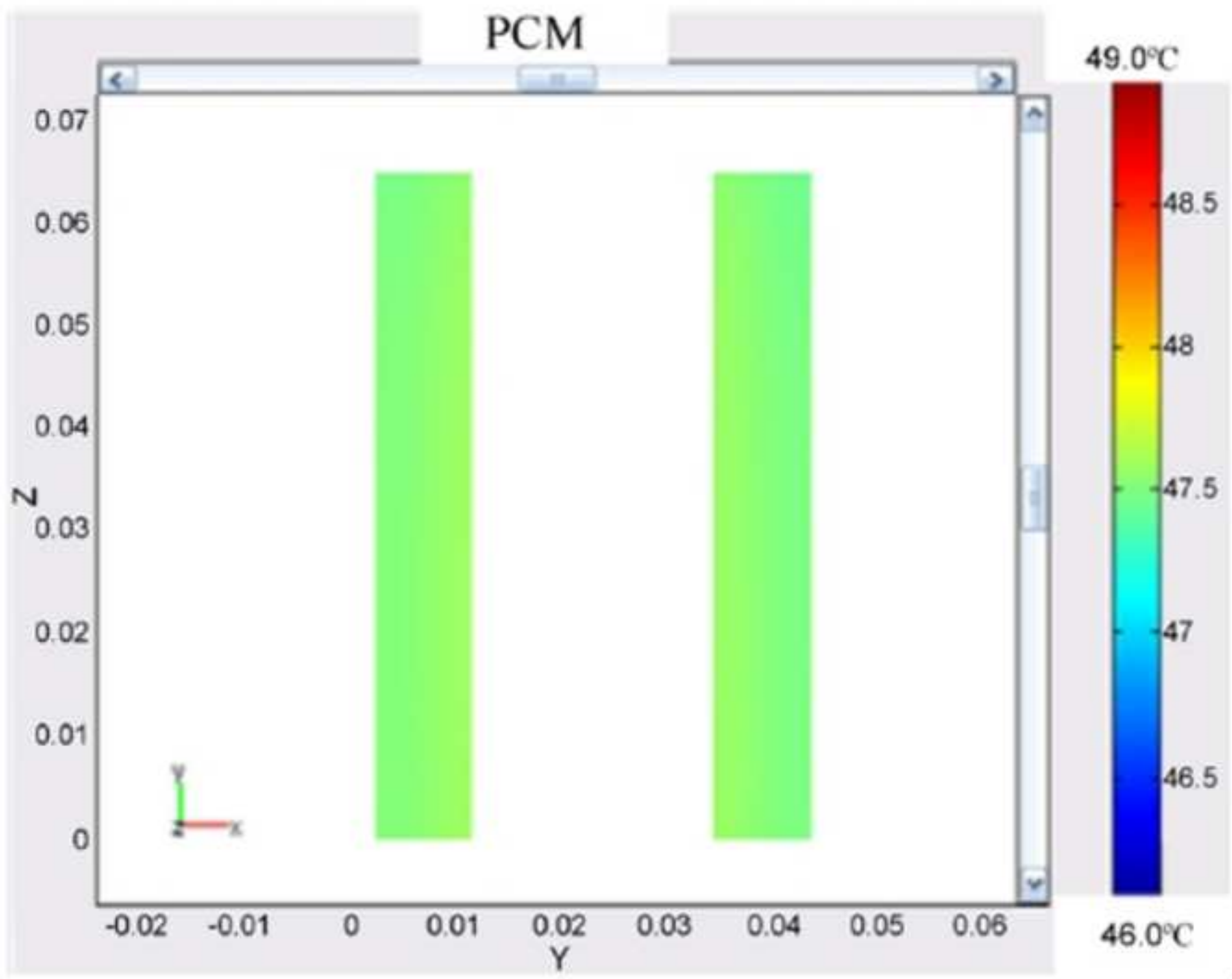




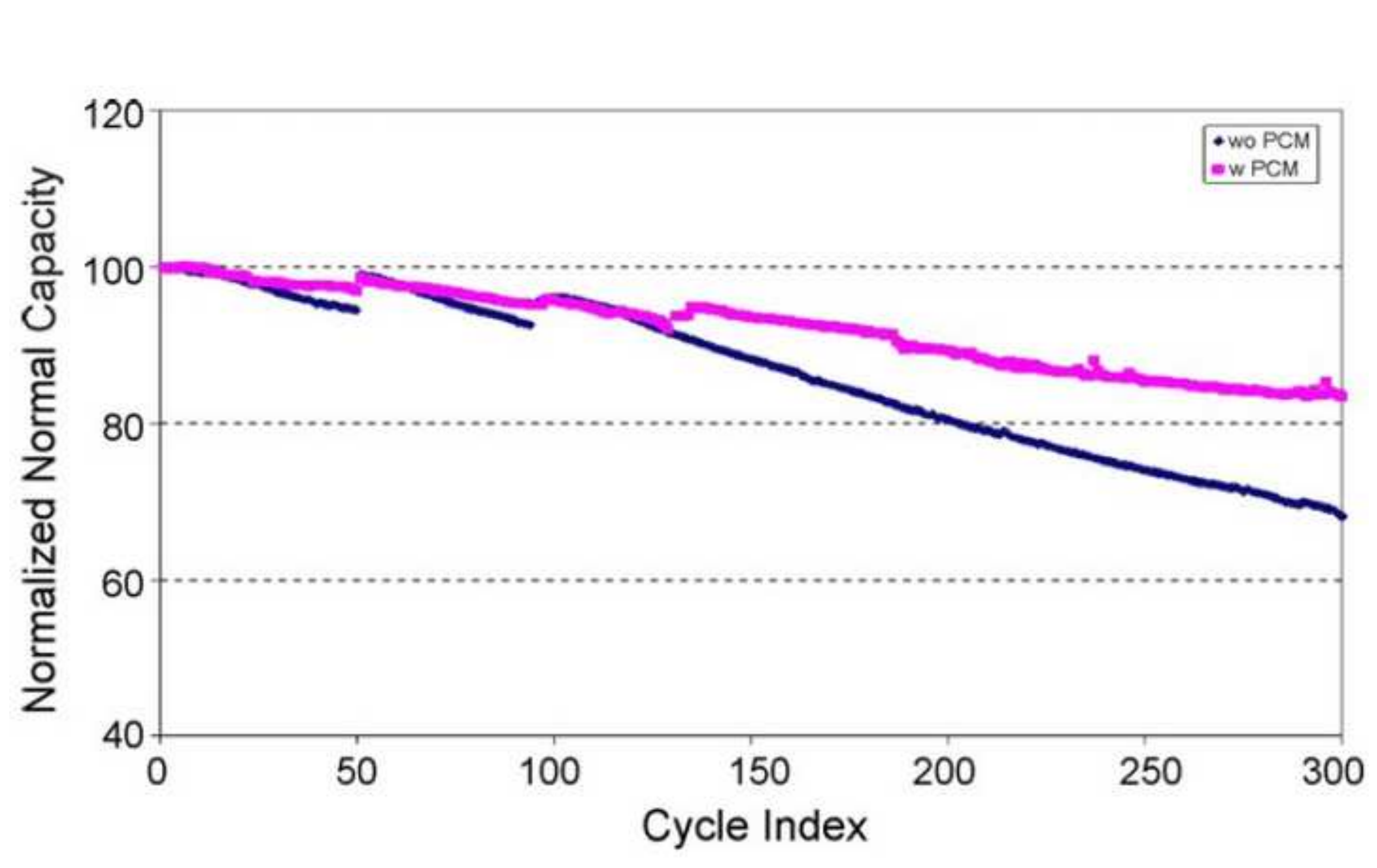




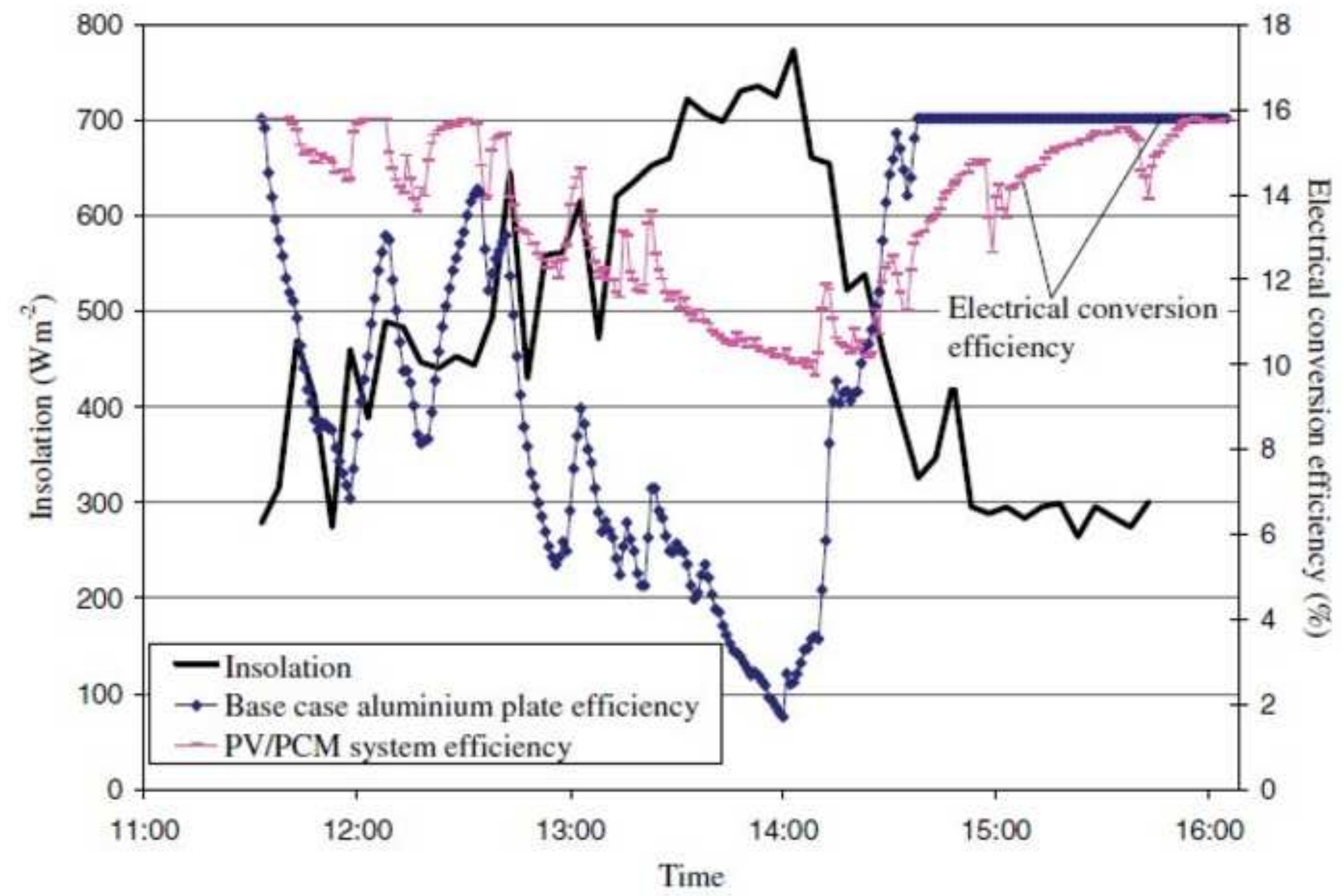



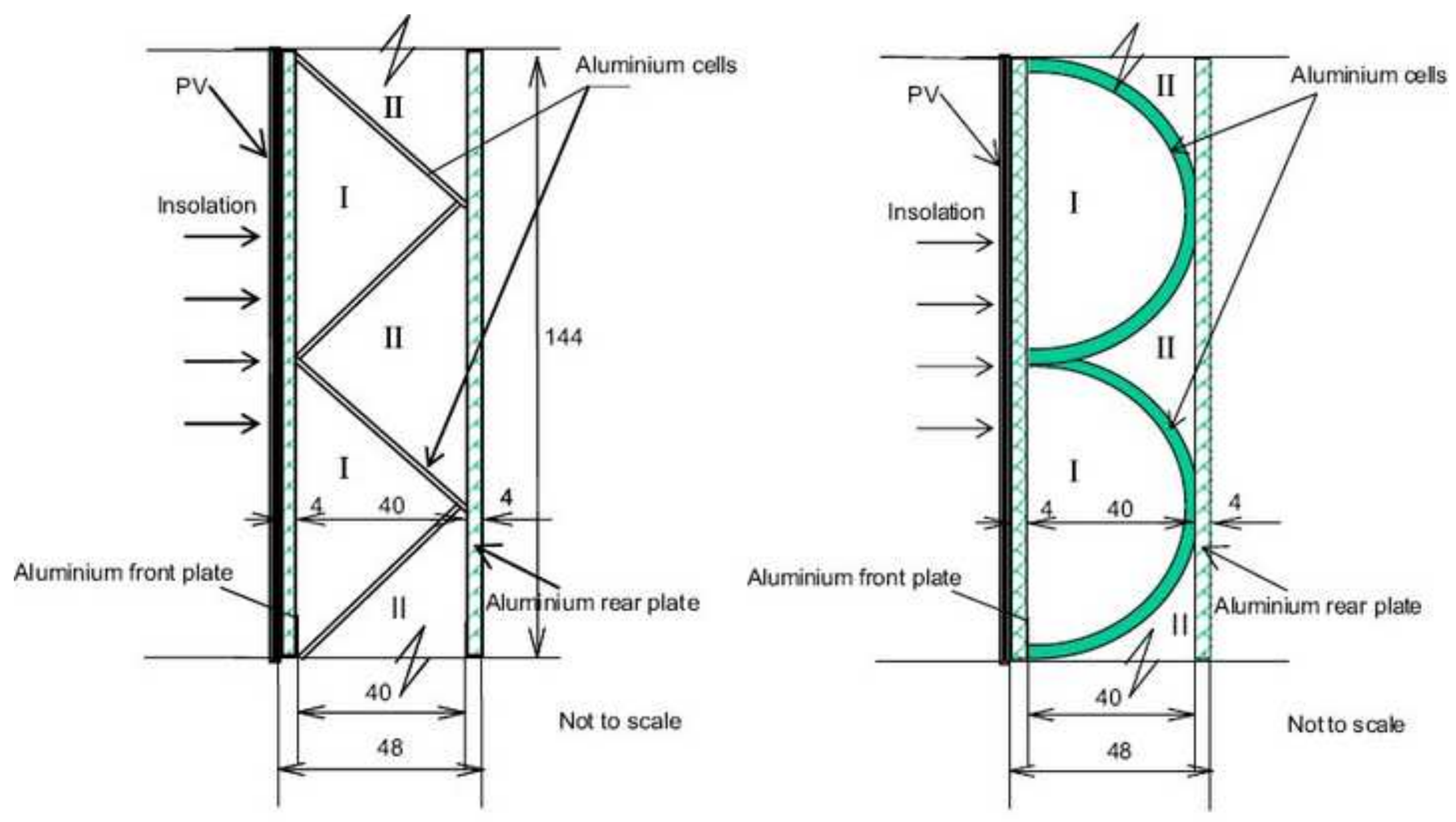


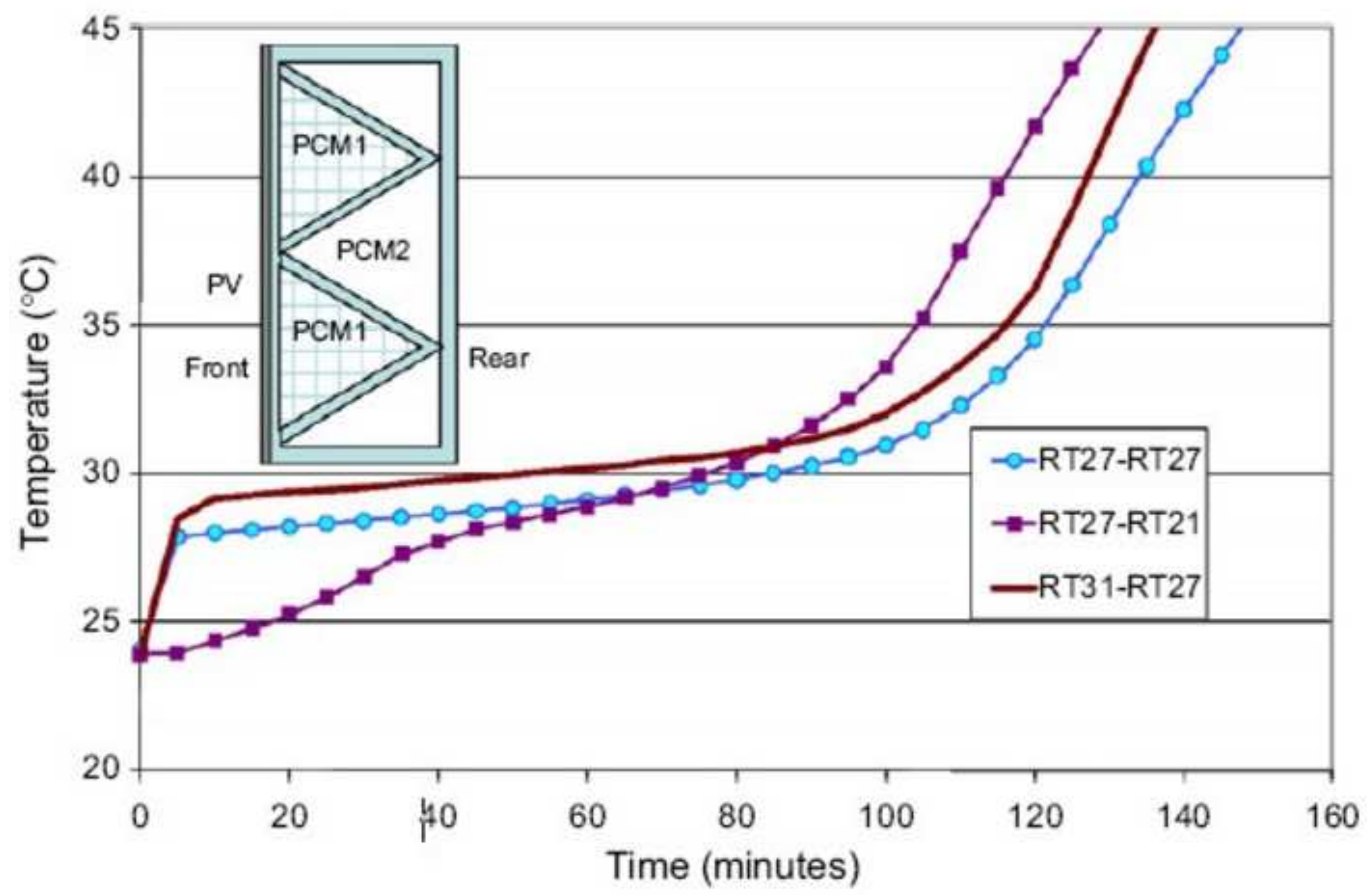


(a)

\section{Hot water outlet}

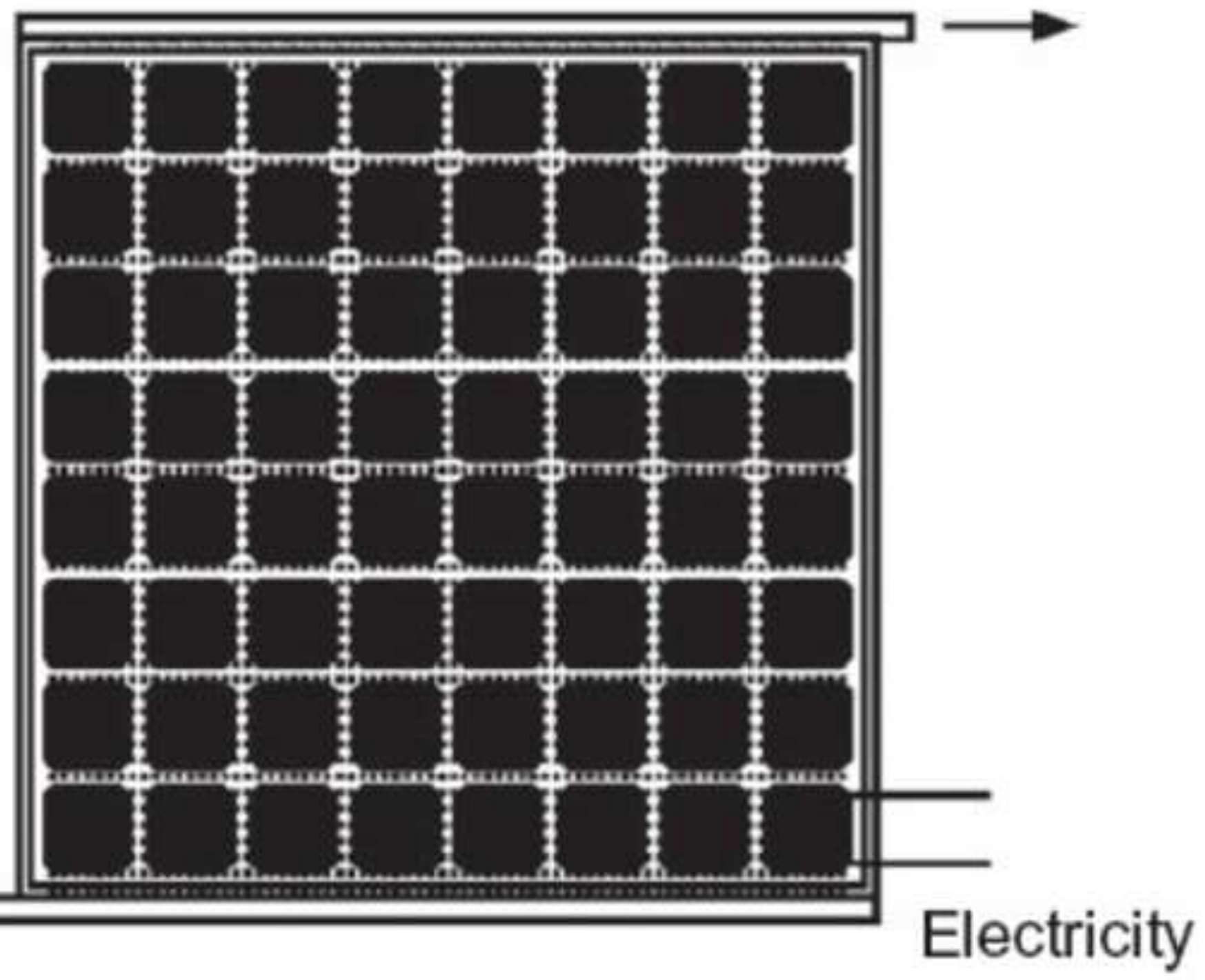

Cold water inlet 


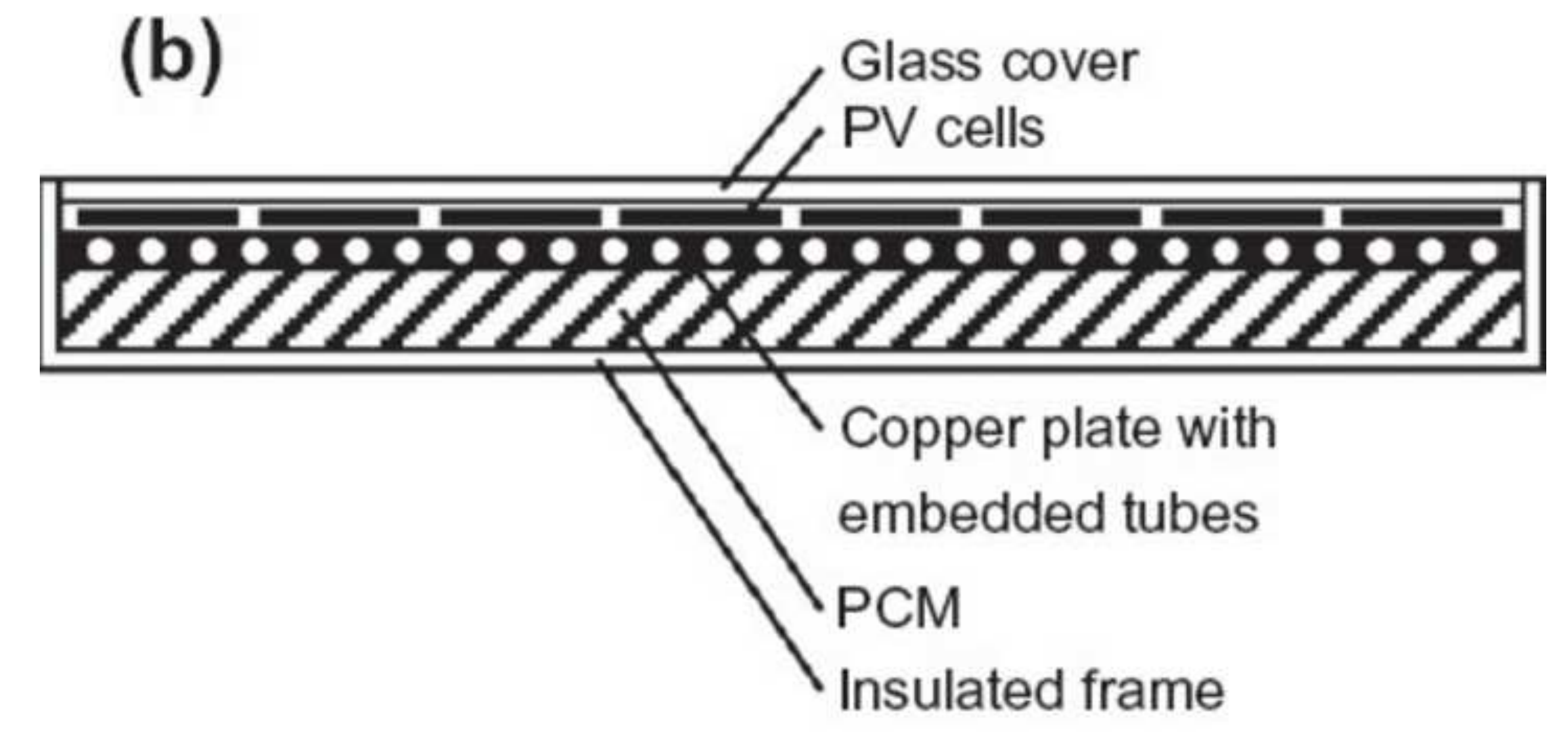

(b)

Glass cover PV cells

Insulated frame 


\section{To back-up}

PV/ST/PCM

boiler

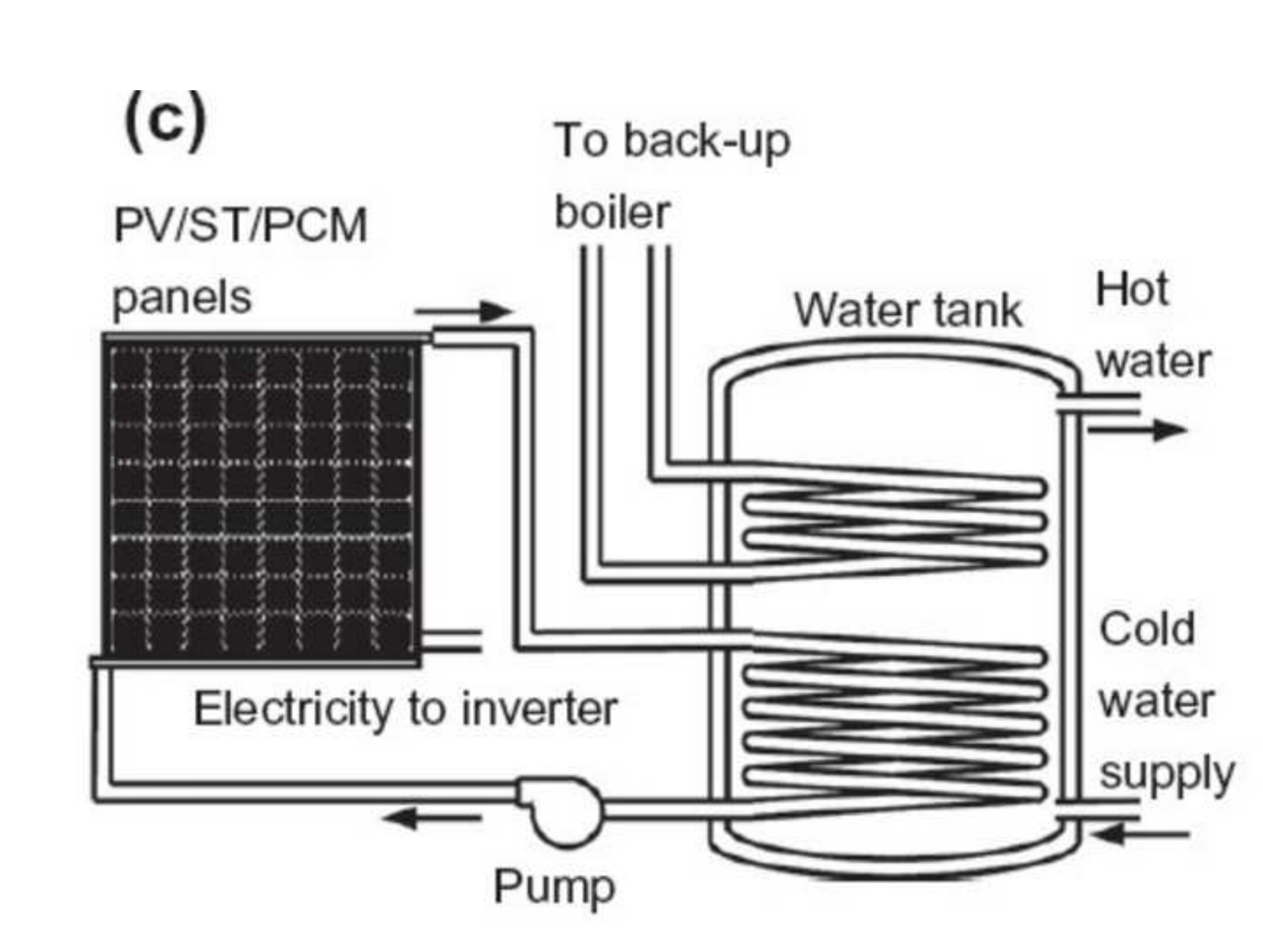

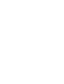




\begin{tabular}{|c|c|c|c|c|c|}
\hline Authors & $\begin{array}{l}\mathrm{PCM} / \\
\text { Thermal conductivity } \\
\left(\mathrm{W} \mathrm{m}^{-1} \mathrm{~K}^{-1}\right)\end{array}$ & $\begin{array}{l}\text { Additives/ } \\
\text { Thermal conductivity } \\
\left(\mathrm{W} \mathrm{m}^{-1} \mathrm{~K}^{-1}\right)\end{array}$ & $\begin{array}{l}\text { Composites } \\
\text { thermal } \\
\text { conductivity } \\
\left(\mathrm{W} \mathrm{m} \mathrm{m}^{-1} \mathrm{~K}^{-1}\right)\end{array}$ & $\begin{array}{l}\text { Ratio of } \\
\text { composit } \\
\text { e } \\
(\% \mathrm{wt})\end{array}$ & $\begin{array}{l}\text { Latent heat of } \\
\text { PCM without/ } \\
\text { with additives } \\
\left(\mathrm{kJ} \mathrm{kg}^{-1}\right)\end{array}$ \\
\hline Mills et al. [37] & RT-42 paraffin/ 0.2 & $\begin{array}{l}\text { Expanded graphite/ } \\
4-100\end{array}$ & 16.6 & 26.6 & $250 / 185$ \\
\hline Alva et al. [38] & Paraffin/ 0.2 & Graphite & 70 & 35 & $179 / 136$ \\
\hline Cheng et al. [39] & Paraffin/ 0.31 & Graphite powder/ 2-90 & 0.46 & 12 & $133.1 / 90$ \\
\hline $\begin{array}{c}\text { Darkwa and Zhou } \\
{[40]}\end{array}$ & Hexadecane /0.15 & Aluminium particles & 1.25 & & $236 / 167$ \\
\hline Frusteri et al. [25] & Inorganic eutectic/ 0.47 & Carbon fiber/ $175-200$ & 1.8 & $8 \%$ & $195 / 180$ \\
\hline Hasse et al. [41] & Paraffin/ 0.193 & $\begin{array}{l}\text { Aluminium } \\
\text { honeycomb panel/ } 160\end{array}$ & & & $170 /$ \\
\hline $\begin{array}{c}\text { Karaipekli et al. } \\
\text { [42] }\end{array}$ & Stearic acid/ 0.3 & $\begin{array}{l}\text { Carbon fiber/ } 190 \\
\text { Expanded graphite/ } \\
4-100\end{array}$ & $\begin{array}{l}0.62 \\
0.8\end{array}$ & $\begin{array}{l}10 \\
10\end{array}$ & $\begin{array}{l}198.8 / 184.6 \\
198.8 / 183.1\end{array}$ \\
\hline Li et al. [43] & N-octadecane/ 0.27 & $\begin{array}{l}\text { Expanded graphite/ } \\
4-100\end{array}$ & 1.07 & 16.7 & $232 / 189$ \\
\hline Sari et al. [44] & N-docosane/ 0.22 & Graphite powder/ 2-90 & 0.82 & 10 & $94.6 / 178.3$ \\
\hline Siahpush et al. [45] & Eicosane/ 0.423 & Copper porous foam & 3.06 & $95 \%$ & \\
\hline Wang et al. [36] & $\begin{array}{l}\text { Polyethylene glycol/ } \\
0.299\end{array}$ & $\begin{array}{l}\text { Expanded graphite/ } \\
4-100\end{array}$ & 1.324 & 10 & $187.3 / 161.2$ \\
\hline Yin et al. [46] & Paraffin/ 0.2697 & $\begin{array}{l}\text { Expanded graphite/ } \\
4-100\end{array}$ & 4.676 & 6.25 & \\
\hline Zeng et al. [47] & 1-Tetradecanol/ 0.32 & Ag nanowire & 1.46 & 62.73 & $210 / 76.5$ \\
\hline Zhang et al. [48] & N-octadecane / 0.1505 & $\begin{array}{l}\text { Inorganic silica shell/ } \\
1.3\end{array}$ & 0.6213 & 50 & $214.6 / 123$ \\
\hline
\end{tabular}




\begin{tabular}{|c|c|c|c|c|c|c|c|c|}
\hline Author & Cathode/ Anode & $\begin{array}{l}\text { Depth of } \\
\text { discharge } \\
\text { (DOD) range }\end{array}$ & $\begin{array}{l}\text { Cycle } \\
\text { rate }\end{array}$ & $\begin{array}{l}\text { Cycle } \\
\text { numbers }\end{array}$ & $\begin{array}{l}\text { Test } \\
\text { temperature }\end{array}$ & $\begin{array}{l}\text { Loss of } \\
\text { capacity }\end{array}$ & $\begin{array}{l}\text { Loss of } \\
\text { Power }\end{array}$ & $\begin{array}{l}\text { Possible mechanisms of power/capacity } \\
\text { fade }\end{array}$ \\
\hline \multirow{4}{*}{$\begin{array}{l}\text { Zhang et al. } \\
\text { [77] }\end{array}$} & \multirow{4}{*}{$\mathrm{C} / \mathrm{LiFePO}_{4}$} & \multirow{4}{*}{$3.6-2.0 \mathrm{~V}$} & \multirow{4}{*}{$3 C$} & \multirow{4}{*}{600} & $-10^{\circ} \mathrm{C}$ & $25.8 \%$ & $77.2 \%$ & \multirow{4}{*}{$\begin{array}{l}\text { Increased interfacial resistance and } \\
\text { electrolyte resistance are the main sources } \\
\text { for power fade }\end{array}$} \\
\hline & & & & & $0{ }^{\circ} \mathrm{C}$ & $20.3 \%$ & $61.6 \%$ & \\
\hline & & & & & $25^{\circ} \mathrm{C}$ & $15.5 \%$ & $16.2 \%$ & \\
\hline & & & & & $45^{\circ} \mathrm{C}$ & $14.3 \%$ & little & \\
\hline \multirow{2}{*}{$\begin{array}{l}\text { Liu et al. } \\
{[79]}\end{array}$} & \multirow{2}{*}{$\mathrm{C} / \mathrm{LiFePO}_{4}$} & \multirow{2}{*}{$90 \%$ DOD } & \multirow{2}{*}{$\mathrm{C} / 2$} & 757 & $60^{\circ} \mathrm{C}$ & l & / & \multirow{2}{*}{$\begin{array}{l}\text { The loss of active lithium consumed to } \\
\text { repair the SEI layer is blamed for the } \\
\text { capacity fade. }\end{array}$} \\
\hline & & & & 2628 & $15^{\circ} \mathrm{C}$ & l & / & \\
\hline \multirow{3}{*}{$\begin{array}{l}\text { Amine et al. } \\
{[80]}\end{array}$} & \multirow{3}{*}{$\mathrm{MCMB} / \mathrm{LiFePO}_{4}$} & \multirow{3}{*}{$3.8-2.7 \mathrm{~V}$} & \multirow{3}{*}{$C / 3$} & \multirow{3}{*}{100} & $25^{\circ} \mathrm{C}$ & 0 & / & \multirow{3}{*}{$\begin{array}{l}\text { Precipitation of metal iron on the graphite } \\
\text { surface accelerates the formation and } \\
\text { growth of interfacial films over the anode } \\
\text { which causes the capacity fade }\end{array}$} \\
\hline & & & & & $37{ }^{\circ} \mathrm{C}$ & $55 \%$ & / & \\
\hline & & & & & $55^{\circ} \mathrm{C}$ & $72 \%$ & I & \\
\hline \multirow[b]{2}{*}{$\begin{array}{l}\text { Wright et al. } \\
\text { [81] }\end{array}$} & \multirow[b]{2}{*}{$\mathrm{C} / \mathrm{LiNi}_{0.8} \mathrm{Co}_{0.15} \mathrm{Al}_{0.05} \mathrm{O}_{2}$} & \multirow[b]{2}{*}{$4.1-3.0 \mathrm{~V}$} & \multirow[b]{2}{*}{$C / 1$} & \multirow[b]{2}{*}{369,600} & $25^{\circ} \mathrm{C}$ & I & $17.7 \%$ & \multirow{2}{*}{$\begin{array}{l}\text { Growth of SEI and changes in properties of } \\
\text { separator possibly cause the capacity and } \\
\text { power fade. }\end{array}$} \\
\hline & & & & & $45^{\circ} \mathrm{C}$ & $\begin{array}{l}1.5 \text { times } \\
\text { higher than } \\
25^{\circ} \mathrm{C}\end{array}$ & $32.7 \%$ & \\
\hline \multirow{2}{*}{$\begin{array}{l}\text { Shim et al. } \\
\text { [82] }\end{array}$} & \multirow{2}{*}{$\mathrm{C} / \mathrm{LiNi}_{0.8} \mathrm{Co}_{0.15} \mathrm{Al}_{0.05} \mathrm{O}_{2}$} & \multirow{2}{*}{$4.1-3.0 \mathrm{~V}$} & \multirow{2}{*}{$C / 2$} & \multirow{2}{*}{140} & $25^{\circ} \mathrm{C}$ & $4 \%$ & & \multirow{2}{*}{$\begin{array}{l}\text { Loss of conductive carbon at the cathode } \\
\text { surface might increase the impedance rise. }\end{array}$} \\
\hline & & & & & $60^{\circ} \mathrm{C}$ & $65 \%$ & & \\
\hline \multirow{4}{*}{$\begin{array}{l}\text { Ramadass et } \\
\text { al. }[83,84]\end{array}$} & \multirow{4}{*}{$\mathrm{C} / \mathrm{LiCoO}_{2}$} & \multirow{4}{*}{$4.2-2.0 \mathrm{~V}$} & \multirow{4}{*}{$\begin{array}{l}C / 9 \sim \\
C / 1\end{array}$} & 800 & $25^{\circ} \mathrm{C}$ & $30.63 \%$ & & \multirow{4}{*}{$\begin{array}{l}\text { The loss of capacity is dominated by the } \\
\text { increased rate of lithium loss and drastic } \\
\text { increase in the negative resistance. }\end{array}$} \\
\hline & & & & 800 & $45^{\circ} \mathrm{C}$ & $36.21 \%$ & & \\
\hline & & & & 500 & $50^{\circ} \mathrm{C}$ & $43.21 \%$ & & \\
\hline & & & & 500 & $55^{\circ} \mathrm{C}$ & $70.56 \%$ & & \\
\hline $\begin{array}{l}\text { Kim et al. } \\
{[85]}\end{array}$ & $\mathrm{C} / \mathrm{LiFePO}_{4}$ & $3.8-2.0 \mathrm{~V}$ & $4 C$ & $\begin{array}{l}1000 \sim \\
3000\end{array}$ & $\begin{array}{l}\text { Room } \\
\text { temperature }\end{array}$ & $10 \sim 15 \%$ & & $\begin{array}{l}\text { Capacity fades due to the loss of active } \\
\text { lithium and power fades due to the rising } \\
\text { interfacial resistance of the anode. }\end{array}$ \\
\hline
\end{tabular}




\begin{tabular}{lcccc}
\hline PCM Name & Capric acid & Eicosane & $\mathrm{Na}_{2}\left(\mathrm{SO}_{4}\right) 10 \mathrm{H}_{2} \mathrm{O}$ & $\mathrm{Zn}\left(\mathrm{NO}_{3}\right)_{2} 6 \mathrm{H}_{2} \mathrm{O}$ \\
\hline PCM Number & 1 & 2 & 3 & 4 \\
Melting Temperature $\left({ }^{\circ} \mathrm{C}\right)$ & 31.4 & 36.7 & 32.3 & 36.2 \\
Density $\left(\mathrm{kg} \mathrm{m}^{-3}\right)$ & 884 & 778 & 1,485 & 2,065 \\
Latent Heat $(\mathrm{kJ} / \mathrm{kg})$ & 153 & 241 & 254 & 147 \\
Thermal Conductivity $\left(\mathrm{W} \mathrm{m}^{-1}{ }^{\circ} \mathrm{C}^{-1}\right)$ & 2 & 0.27 & 0.544 & 0.31 \\
Specific Heat $\left(\mathrm{kJ} \mathrm{kg}^{-10} \mathrm{C}^{-1}\right)$ & 2.09 & 1.90 & 1.930 & 1.34 \\
\hline
\end{tabular}

